NBER WORKING PAPER SERIES

\title{
THE HISTORY AND POLITICS OF CORPORATE OWNERSHIP IN SWEDEN
}

\author{
Peter Högfeldt \\ Working Paper 10641 \\ http://www.nber.org/papers/w10641
NATIONAL BUREAU OF ECONOMIC RESEARCH 1050 Massachusetts Avenue
Cambridge, MA 02138
July 2004

Special thanks to Martin Holmén for help and comments and to Jan Glete for providing data. I have benefited from constructive discussions and comments by Marco Becht, Lennart Erixon, Silvia Giacomelli, Colin Mayer, Randall K. Morck, Marco Pagano, Krishna Palepu, Raghuram G. Rajan, Ailsa Roell, Örjan Sjöberg and Steen Thomsen, as well as from participants at the University of Alberta Business School and NBER conference at Lake Louise, Alberta, Canada, June 21-22, 2003 and participants at the CEPR/ECGI/INSEAD/ NBER/University of Alberta joint conference on The Evolution of Corporate Governance and Family Firms in Fontainebleau January 30-31, 2004 for valuable comments. I also appreciate the generosity of The Bank of Sweden Tercentenary Foundation. An article based on this paper was published in the European and US editions of Financial Times on October 16, 2003: Socialist ideal that tied up Swedish riches. The views expressed herein are those of the author(s) and not necessarily those of the National Bureau of Economic Research.

(C2004 by Peter Högfeldt. All rights reserved. Short sections of text, not to exceed two paragraphs, may be quoted without explicit permission provided that full credit, including $(\subset$ notice, is given to the source. 
The History and Politics of Corporate Ownership in Sweden

Peter Högfeldt

NBER Working Paper No. 10641

July 2004

JEL No. G3, N2, N4

\section{$\underline{\text { ABSTRACT }}$}

Not despite but because of persistent Social Democratic political influence since the Great Reversal in 1932 have a few families and banks controlled the largest listed firms in Sweden. The Social Democrats have de facto been the guarantor rather than the terminator of private capitalism since the political and corporate incumbencies have been united by strong common interests. Incumbent owners need the political support to legitimize that their corporate power rests on extensive use of dual-class shares and pyramiding. While the Social Democrats only get the necessary resources and indirect support for their social and economic policies from the private sector if the largest firms remain under Swedish control so that capital does not migrate. The extensive use of mechanisms to separate votes from capital however drives a significant wedge between the costs of internal and external capital that causes an enhanced (political) pecking order of financing where new external equity is strongly avoided. By not encouraging outsiders to create new firms and fortunes, and by not fully activating the primary equity markets, the heavy politicized system has redistributed incomes but not property rights and wealth. The result is an ageing economy with an unusually large proportion of very old and very large firms with well-defined owners in control. 31 of the 50 largest listed firms in 2000 were founded before 1914, only 8 in the post-war period and none after 1970.

Peter Högfeldt

Department of Finance

Stockholm School of Economics

Box 6501

SE-113 81Stockholm

Sweden

peter.hogfeldt@hhs.se 
One of the ironies of European business history of the $20^{\text {th }}$ century is the relative stability (resiliency) of corporate ownership structures despite the unprecedented political turmoil with devastating wars and the interregnum of socialism. It is however still impossible to understand the strong historical path dependence without analyzing how political factors have profoundly affected the development of corporate ownership by first setting the stage and then changing the conditions in systematic ways (see e.g. Roe (2002a and b)). Not only through the design of the legal system (regimes) and corporate laws, and the efficiency of legal enforcement and supervision. But also by changing the balance of interests between labor and capital by regulation of labor, product and capital markets, and development of tax-financed, public welfare systems with egalitarian ambitions to redistribute resources and opportunities.

Another historical irony is that previous adversarial relations between capital and labor have given way to a corporatist society where heavily entrenched private ownership of the largest listed firms co-exits and cooperates with labor unions whose members enjoy strong employee protection, and are represented on the board (see Pagano and Volpin (2001)). Since financial markets are conducive to structural changes, which often run counter to the status quo interests of incumbent labor and capital, they tend to be less developed in corporatist countries, and firms also less dependent on external financing through equity markets (see e.g. Rajan and Zingales (2003a)). This is particularly true in Continental Europe and in Scandinavia where proportional voting systems tend to favor formation of minority or coalition governments and consensus decision making, which fosters political rent seeking by the firms' stakeholders, and larger public sectors. ${ }^{1}$ Corporate ownership in a country does therefore not only rest on the corporate law and on the legal regime but ultimately on the political acceptance at large of entrenched private ownership. The

\footnotetext{
${ }^{1}$ In a cross-country analysis of the relation between political institutions and policy outcomes, Persson and Tabellini (2003) find that presidential regimes have smaller governments than parliamentary systems. Majoritarian elections induce smaller governments, less welfare spending and smaller deficits than do proportional elections. In particular, they report systematic differences in spending patterns: Proportional and parliamentary democracies alone display a ratchet effect in spending, with government outlays as a percentage of GDP rising in recessions, but not reverting in booms. All countries cut taxes in election years. Presidential regimes postpone fiscal contractions until after the elections, while parliamentary regimes do not; welfare-state programs are expanded in the proximity of elections, but only in democracies with proportional elections.
} 
structure of corporate ownership and governance, as well as the development of the financial system, are thus very much integrated parts of a country's political history.

But how do the economic, political, legal and historical conditions interact? The challenge in comparative historical analysis of corporate ownership is to try to separate which factors are primarily exogenous and which are predominantly endogenously determined, and then evaluate their relative importance and causal relations by comparing the realized, historical paths across countries. History is of course not deterministic since the actual equilibrium path is only one of many possible and temporary random events like financial crises and subsequent regulatory responses may have long-term effects through path dependence (see Rajan and Zingales (2003b)). The underlying assumption is thus that there is enough structural stability in societies for the comparative analysis to map out the major decisive factors of corporate ownership over time.

This is of course a very tall order but fortunately some institutions and factors (e.g. constitutions, legal regimes and enforcement, economic geography) are surprisingly stable over time and therefore natural candidates as exogenous determinants in the causal, historical analysis. Protection of property rights, freedom of contracting and the openness of the civic society have basically been exogenous factors over a longer time period but sometimes exposed to the strong winds of political change. Changes in external competition and major technological changes are also primarily exogenous, in particular for a small open market economy, and often catalysts for structural changes. Other pivotal factors have a much less exogenous character since they are more influenced by changing economic and political conditions. For example, the domestic economy's openness to trade and capital flows, choice of exchange rate regimes and policies to promote flexible labor markets and development of financial markets. The strongest endogenous factor in the $20^{\text {th }}$ century has definitely been how political ideology (e.g. socialism or egalitarianism) in general, and voice of parties and organized stakeholders, in particular labor, have rallied political support for and implemented policies that absorb and assuage effects of brute, tempestuous markets forces. 
This paper contributes to the comparative historic analysis by analyzing which factors (economic, legal, historical and political) were decisive in the historical development of corporate ownership (listed firms) in Sweden. In fact, Sweden is a rather suitable case for a causal analysis since several economic factors are exogenously determined by the fact that it is a small and exportoriented economy that has exploited it base of natural resources and supplied Europe with raw materials and manufacturing goods. Institutional and political conditions have also been very stable since the country benefited politically and economically by staying out of the two wars. In particular the political stability has been unprecedented among Western democracies.

The Social Democratic Party (SAP) has been in power since 1932 except for 9 years between 1976-82 and 1991-94 but predominantly as a single party minority government with passive support from the Communist (later Socialist) Party (SKP, VPK and Vänsterpartiet, respectively), and more recently also from the Environmental Party (Miljöpartiet) or in coalition or with support from the Farmers' party (Bondeförbundet, later Centerpartiet). Consistent with the corporatist spirit in society, the relation between the well-organized interests of capital and labor has in general been cooperative and consensus oriented, and property rights have been respected. The exceptions to this rule are two major political conflicts in the late 40s (about a far-reaching, governmental interventionist program for a more planned economy to fight an expected post-war depression) and in the late 70 s and early 80 s (about a proposal for partial transfer of corporate control to the labor unions), which both resulted in electoral set-backs for the Social Democrats and in implementation of significantly watered-down programs that later were terminated.

Despite recurrent financial and industrial crises, and increasing capital demands, corporate control of the largest firms has been remarkably stable and increasingly concentrated since the 1930s. The political intervention and general influence in the economy at large has however been significant, and embodied in an unusually large tax-financed public sector that redistributes resources and opportunities between citizens in a very ambitious manner. The mixture of institutional stability, persistent social democratic policies and stable, concentrated corporate 
ownership in a small open economy exposed to international competitive pressure makes Sweden a particularly interesting case.

I focus on three major questions about the history and politics of corporate ownership. First, given the changing economic and political conditions, which factors caused the ownership of the largest listed firms to become so concentrated and stable over time? And which are the economic consequences thereof? Since stability breeds complacency, lock-in of inherited capital and political rent seeking, in particular if firms are controlled by families and banks, it is important to track the effects on investments, $R \& D$, overall growth and creation of new firms; where does the new entrepreneurial blood come from (see e.g. Morck, Strangeland and Yeung (2000) and He, Morck and Yeung (2003))?

Second, the relation between labor and capital has not been without tension, but why did the very strong egalitarian ambitions of the labor movement (the blue-collar union LO and the Social Democratic Party-- SAP) made a halt at private ownership and accepted that the control of the largest firms via pyramids and extensive use of dual-class shares rests with a very small elite of old families and professional managers? Why does one of the most egalitarian societies accept one of the most unequal distributions of power over large corporations? Neither lasting influence of an antithetical political ideology nor ambitious redesign by occupational powers (Germany and Japan) seems thus to hinder established mechanisms of corporate control from reproducing (replicating) themselves in democracies. But why are the control mechanisms so strong that they survive the whirlwinds of political and social change?

The third question concerns how the structure of the financial system has influenced and shaped corporate ownership and how ownership in turn has affected the development of the financial system, in particular of the primary equity markets. The question is of course motivated by the influential literature on law and finance that finds correlations between e.g. civil law origin dummy (significant regression coefficient), more concentrated ownership and less developed financial markets (see e.g. La Porta, Rafael, Florencio Lopez-de-Silanes, Andrei Shleifer and 
(Robert Vishny) (1999) and (2000)). Are there other factors besides the degree of legal protection of minority shareholders that explains why ownership did not become dispersed in Sweden? Does e.g. Mark Roe's idea that ownership and control does not separate in Continental Europe because the pressure of social democracy (in a wide sense, not necessarily political party) also apply to the perhaps most social democratic society in Europe, Sweden?

I provide an integrated answer to the three closely related questions by focusing on a narrow financial perspective: How did the firms finance their investments? Or more specifically: How dependent have listed firms been on external capital from the primary equity market? ${ }^{2}$ The importance of political, social and external economic factors will be analyzed from the perspective of how they have influenced and shaped the firm's dependence on external equity financing. The basic idea is that ownership will only become dispersed if firms need to raise a significant part of their capital in the external equity markets, and that political decisions will determine how dependent firms are on external financing. Political support for use of pyramids and dual-class shares that separate votes from capital will limit the controlling owners' as well as the firm's dependence on equity markets. This occurs because the separation of ownership from control drives a significant wedge between the costs of internal and external capital as new external shareholders demand compensation (discounts) for the associated agency costs. But the firm's internal capital is comparatively inexpensive for the controlling owners as they have access to and exert power over

\footnotetext{
${ }^{2}$ My ideas have been inspired by Rajan and Zingales (2003 a and b) and their interest group theory of financial development where incumbents oppose development when it breeds competition. My analysis of the Swedish case may be regarded as an application and elaboration of their basic framework by its focus on the interaction between political ideology and corporate ownership. Another great inspiration is Mark Roe's political theory about social democracy (Roe (2002a) and his views on corporate law and corporate governance (Roe (2002b)) although I disagree on some points. My analysis deviates from the interesting approach to a new political economy surveyed and developed by Pagano and Volpin (2001) and (2004), respectively, since I emphasize the importance of political ideology more strongly than differences in electoral systems but their analysis has been thought-provoking. Erixon (1997) has been an important inspiration and my financial approach may be regarded as complementary to his real analysis of the Swedish industrial development. I have also benefited from Henreksson and Jakobsson (2001 and 2003a and b) that emphasize the negative effect of taxes on corporate ownership and the threat of Socialism to private ownership. But they completely ignore that the existence of pyramids presupposes that inter-corporate dividends as well as capital gains are not taxed; see Morck (2003). Social Democratic governments have over the years implemented such tax policies that are conducive to pyramiding; see Holmén and Högfeldt (2004b). Applying Rajan's and Zingales' general reasoning, I however develop a political theory of corporate ownership and financial markets that generates the diametrically opposite conclusion. The Social Democrats have been the guarantor rather than the threat to entrenched corporate ownership since the political and corporate incumbencies have been united over time by strong common interests. Glete's (1994) historical description and analysis of corporate networks have significantly contributed to my knowledge and ideas about corporate ownership in Sweden.
} 
all of the firm's internal cash flows via a relatively small (less than proportional) capital investment. This generate an enhanced pecking order of financing: Strong reliance on retained earnings and borrowing but avoidance of equity issues, in particular of large public offers as they would dilute control and also be extra costly due to the discounts to new outside shareholders; see Holmén and Högfeldt (2004b). ${ }^{3}$ The enhanced pecking order is reinforced by the key political decision to allow banks to directly or indirectly own equity as the banks are more likely to provide new debt when their closely related firms need capital. The close connections between banks and large listed firms have had profound and lasting effects on corporate financing and ownership in Sweden over the last 100 years.

If capital for investments can be supplied primarily through retained earnings, by borrowing in banks or by infusion of private capital, firms have no immediate need to go through the strictures of equity offers and place a larger fraction of shares with new investors that may dilute the value of their private benefits of control and disperse ownership. The Social Democrats have in particular pursued three policies that tend to reinforce entrenchment of incumbent owners: (i) allowing bank ownership of equity; (ii) strong support for control structures that rigidly separate votes from capital, for a long time also combined with rigorous restrictions on foreign ownership of equity, and (iii) persistently giving retained earnings and borrowing a tax advantage over equity. The policies have de facto disfavored formation of new, fast growing firms over incumbent firms as well as outside equity financing by supporting an enhanced pecking order of financing in established firms.

The real irony is thus that corporate ownership in Sweden is very concentrated not despite but because of persistent Social Democratic policies since the Great Reversal in 1932. The Social Democrats have in fact been the guarantor rather than the terminator of private capitalism since the political and corporate incumbencies have been united by strong common interests. Incumbent owners need the political support to legitimize that their corporate power rests on extensive use of dual-class shares and pyramiding while the Social Democrats only get the necessary resources and

\footnotetext{
${ }^{3}$ The pecking order is enhanced since it is caused by agency costs inherent to the ownership structure and not primarily by asymmetric information costs, and since public offers are very strongly avoided; see Högfeldt and Oborenko (2004).
} 
indirect support for their social and economic policies from the private sector if the largest firms remain under Swedish control so that capital does not migrate.

Before elaborating on these ideas, I start by presenting a general picture of how corporate ownership has developed historically. After an analytical description of how the ideology and policies of the Social Democrats have affected corporate ownership, I develop my simple, political theory of why ownership did not separate widely in Sweden that focuses on the interaction between corporate ownership and development of the primary equity markets. Before presenting an integrated answer to the three main questions of this chapter, I critically evaluate the Swedish model of corporate ownership. To extract some general implications about how history and politics interact, I speculate about the major exogenous and endogenous factors that caused corporate ownership to follow the path it did in Sweden. I conclude by putting my analysis in a wider historical context.

\section{A Stylized History of Corporate Ownership in Sweden}

Starting with economic reforms in the 1860 s (e.g. freedom to establish new firms for men and women and liberalization of foreign trade), Sweden followed a trajectory of fast industrialization with the highest recorded rate of productivity growth between 1870 and 1913; the productivity level was the second lowest in Europe in 1970 (Maddison (1982)). The export-oriented raw material sector expanded very fast as it supplied the booming Western Europe with timber and iron ore. A first wave of (domestic) innovations provided the foundation for new (genius) firms specialized in engineering and manufacturing that became the basis of large export of investment goods: Atlas Copco (1873), L M Ericsson (1876); Alfa-Laval (1883); ASEA (1883); AGA (1904); and SKF (1907). Already before 1914 the newly founded firms represented half of the production value in Swedish engineering. The very rapid industrialization until 1914 took place behind a tariff barrier that averaged about $15 \%$. In a second wave of innovations, primarily international adapted to 
domestic conditions, new firms with domestic consumer goods orientation were founded: Electrolux, Scania-Vabis, Volvo, and SAAB.

The long expansion from 1870, in particular from the 1890 s, to 1914 resulted in radical transformation of all facets of the society. Sweden is a good early example of successful export-lead growth. The public sector, both at the central level and in municipalities, raised very significant amounts of capital in international bond issues (primarily from France and Germany) to finance the large infrastructural investments in e.g. railroads, harbors, cities and housing. Because of very favorable circumstances, the loans were repaid during WWI. As part of the structural reforms, a banking system of Scottish model with deposit banks that issue notes was built. The new firms used almost exclusively retained earnings (about $40 \%$ of profits were reinvested), trade credits, shortterm credit notes and later short-term bank loans combined with bond financing of machinery and buildings (see Gårdlund (1947)). Firms were controlled by a very small circle of shareholders around the founder and his/her family (see Jörberg (1988)).

Commercial banks (equity-backed) developed fast from the 1870s when the regulation of interest rates was abandoned. But bank loans did not become an important source of industrial financing until around 1900. The banking industry was well organized and had political support since an efficient banking system was regarded as crucial for the development of a relatively poor country. Because of the large export-lead industrial expansion after 1900, a relatively large external equity financing became necessary. More organized and regular trading started at The Stockholm Stock Exchange in 1901 as equity replaced the traditional bond financing and borrowing from banks increased rapidly in response to the increasing demand for capital. The development of the financial system in Sweden seems to be demand-driven as new institutions and regulation adjusted to the changing conditions.

However, despite significant increase in demand for investment capital from the rapidly growing export-oriented industries (manufacturing and raw material-based industries) after 1900 when the equity market became more important, the capital flows were mainly directed through the banking 
system. After heavy lobbying from the banking industry, the Banking Act of 1911 allowed banks to directly own shares and operate as investment banks; the leading bankers controlled the public commission that wrote the law (see Fritz (1990)). The German banking system was now the role model since significant infusion of new capital via the (universal) banking system was argued to be the key to the German economic success. The banks fuelled the speculative stock market boom of the 10 s and 20 s both by helping clients to lever up their portfolios and by buying most of the relatively frequent equity issues via highly levered, stock-financed so called Issuing Companies (Emissionsbolag) that were very closely affiliated with the banks (see Östlind (1944)). The established, relation-based banking system thereby extended its influence and control also to the new equity market that developed too late to become a large independent supplier of risk capital before the financial markets de facto closed down in the $30 \mathrm{~s}$.

After the crises in the early 20 s the banks owned a significant number of shares in the major listed firms and became the controlling owner; see Table 1. However, since the innovators that founded the first generation of firms were not equally successful as business men, they often lost control, particularly after financial crises, or the control of their family was diluted. Given the rather advanced technical character of the firms, an outside professional manager with background in engineering and management was often hired to run the firm. That the banks became controlling owners reinforced this tendency as they lacked the competence to run the firms themselves. The previously privately controlled firms that dispersed their ownership already when issuing new equity to finance their investments in the $10 \mathrm{~s}$ and $20 \mathrm{~s}$, in effect came to be run by the management under supervision of the controlling bank. It is thus no surprise that the overwhelming majority of the 25 largest firms in 1925 are de facto run by the CEO. In fact, an interesting feature of corporate ownership in Sweden until after the WWII is the very strong position of the CEO who most often did not own any shares but often had a significant support from minority shareholders. There are examples where the CEO won battles with the largest owners by accumulating the votes of the minority shareholders. The firms were frequently more identified with their CEO than with their 
controlling owners; there are several cases where the CEO built a dynasty by letting his son or son in law succeed him. ${ }^{4}$

After the financial crises in the 30s when banks owned very large portfolios of listed stocks and de facto controlled the largest, listed firms, the Swedish 1934 (light) version of Glass-Steagall prohibited them to directly own equity but a few years later they were allowed to transfer their assets to holding companies if the shares were distributed to the bank's shareholders. The controlling owners of the banks thus maintained control, and, in effect, reinforced it, since the holding companies were formally separated from the banks but were organized as (listed) closedend- investment funds (CEIFs) that became the pivotal entity around which the typical three-level Swedish ownership pyramid is built: a controlling family or bank foundation at the apex and the listed portfolio firms at the bottom that are controlled via the CEIF at the intermediate level. Figure 1 illustrates the transparent three-level structure of the Wallenberg ownership pyramid in 1996 with Investor in the middle as the pivotal control vehicle of the largest listed firms in Sweden, and the tax-exempt family foundations at the top.

Investor was founded by the Wallenberg-controlled Stockholms Enskilda Bank (today SEB) while Industrivärden, the other leading holding company (CEIF), was founded by the managementcontrolled Svenska Handelsbanken (SHB). Starting already in the 20s, the banks exercised more influence as shareholders and sometimes also as controlling owners at the same time as being the major provider of loans. Since the equity markets de facto closed down in the 30 s, the banking law made the financial capital the dominant supplier of capital and the bankers became business leaders even if the CEOs had a strong position without owning shares. The banks restructured the financially distressed Swedish industrials using intermediated capital and active management of their portfolio. A combination of political conditions and financial crises reversed the road to dispersed ownership.

\footnotetext{
${ }^{4}$ For example, three generations of Laurin were CEOs of PLM without owning any shares and despite that one father warned the owners to let his son succeed him.
} 
It is particularly interesting to observe that the two pivotal reforms of bank ownership in 1911 and 1934 both had the strong support of the Social Democrats; without their votes together with the Liberals in 1911, there would not have been any reform. ${ }^{5}$ They wrote the new law in 1934 after gaining power in 1932. When the Social Democrats formed their first minority government in 1920, Hjalmar Branting appointed Johannes Hellner, head of the legal department at Stockholms Enskilda Bank, to finance minister.

Because of a sequence of pivotal political decisions, supported both by the Social Democrats and the political voice of leading capitalists, listed firms in Sweden have primarily relied on retained earnings - the traditional but also significantly tax subsidized way of financing-- and bank loans but have only to a very limited extent issued new shares. The largest firms were linked to their main bank as supplier of credits while the firm's deposited money and did their banking with their hausbank. Analyzing credit contracts between listed firms and large banks between 1916 and 1947, Sjögren (1995) finds that 46 of 50 non-financial, listed firms entered contracts that lasted for at least 5 years. $40 \%$ of the listed firms had contracts that lasted for the whole period. More than $30 \%$ of the firms had credit, ownership, deposit and bond issuance contracts with only one bank. But the other side of financial interaction was a tight network of pivotal persons around the bank; the controlling owners or CEOs of the listed firms were often represented on the bank's board while representatives of the bank had seats in the firms' boards. Fig 2 illustrates the alliances and very close relations between leading representatives of the major banks, in particular the three largest ones: Enskilda Banken (Wallenberg), Skandinavbanken and Handelsbanken), and industrial firms in 1960 (see Hermansson (1965); former leader of the Communist Party in Sweden). The lines (dotted) indicate a direct (indirect) link between the banks and the main borrowers as the banks' managing directors or board members are members of the board of their main industrial clients.

\footnotetext{
${ }^{5}$ In 1905 Marcus Wallenberg Sr argued that Sweden had great untapped resources, able engineers and good workers but lacked entrepreneurs. His remedy was to start a business school and allow banks to buy shares in listed companies. His family helped found Stockholm's School of Economics in 1909. And his elder half-brother K.A. Wallenberg, chief executive of Stockholm's Enskilda Bank, chairman of the Swedish Bankers' Association and an MP, spearheaded an initiative to allow the largest commercial banks to own shares and to begin acting as investment banks. Against the will of the Conservative government but with the support of the Social Democrats, his proposal was adopted in 1911.
} 
Table 2 shows the ownership and control of the largest listed firms right after the war in 1945. The size of the firms has become significantly larger and owners, in particular the Wallenberg group, have advanced their position even if management control under bank supervision is the norm while control by founding firms has diminished further. Using a Swedish Census on equity ownership from 1945, Lindgren (1953) reports that $6-7 \%$ of shareholders controlled $65-70 \%$ of the market value. Analyzing records from the shareholders' general meetings, he finds that a single individual represented the majority of votes in $60 \%$ of the large firms (more than 500 employees) while three or fewer owners constituted the majority in $+90 \%$ of these firms. In regularly quoted firms, a single individual represented the majority in $53 \%$ of the cases while in $85 \%$ of the firms the two largest owners represented more than $50 \%$ of the votes.

Fig 3 shows the so called 15 families and their controlling interests and financial networks in 1960 that Hermansson (1965) identified as the ultimate controlling owners of the listed firms in Sweden. Of the 50 largest industrial firms 41 are controlled by these families ( 9 are controlled by the state or by cooperatives or municipalities). The government commission on Ownership and influence in private industry (SOU:1968) analyzed the situation in 1963 and identified the same 15 families as well as two bank-related groups as the controlling owners. It is interesting to observe that the 9 families that were closely tied to Handelsbanken and Skadinavbanken do not exert any power today or are significantly marginalized; an exception might be the Klingspors who through their association with the Stenbeck Group still exert power. Of the families with very close personal ties to Enskilda Banken and Investor, the main family, The Wallenbergs, is still in control even if diluted in recent years due to large international mergers (ABB, AstraZeneca and Stora Enso) and concentration of their portfolio investments. While the Bonnier and Johnsson families have been rejuvenated in the $5^{\text {th }}$ generation and are still influential even if their relative position has declined. The Wehtje and Throne-Holst families and to a lesser extent the Söderberg family have been marginalized since 1967 or exert no power today. 
But already in 1967 had the very rapid growth and international expansion of the leading firms in the 50s and 60s undercut the family control of the largest listed firms even if the families more frequently changed to a dual-class structure in order to maintain control when raising new capital. Only $18 \%$ of the largest listed firms used such a control structure in 1950 but almost $1 / 3$ used it in 1968. However, as Table 3 illustrates, the financial capital became dominant and the Wallenberg group in particular had the financial muscles when the equity markets were dormant. The increasing capital demands to establish a large ownership position is also evident from Table 4 that shows the frequency of ownership positions sorted both by size of ownership (capital— not votes) and by size of the 100 largest firms in terms of employment in 1950, 1963, 1978 and 1985. The frequency of small but identifiable holdings have decreased very significantly over the years while the number of larger positions have increased, particularly in the larger firms, which indicates that owners with more capital resources have become more dominant, even without considering their extra voting power due to the frequent use of dual-class shares.

Table 5 shows that in 1990 the largest firms have become significantly larger due mergers and acquisitions while the Wallenbergs remained in control. However, the number of management controlled firms is still high, in particular since three of the most important - Sandvik, Skanska and Volvo- developed an elaborate system of cross-shareholdings to fend off potential hostile takeovers as more developed liquid markets facilitated such endeavors. New financial operators became active during the $80 \mathrm{~s}$ - Anders Wall, Erik Penser, Sven-Olof Johansson to name a fewbut their importance vanished during the $90 \mathrm{~s}$. More recent additions are Carl Bennet, Gustaf Douglas, Sven Hagströmer, Mats Qviberg, Fredrik Lundberg, Melker Schörling and Jan Stenbeck who have built and rebuilt existing firms into controlling groups using entrepreneurial financial skills.

In recent years the Wallenberg power sphere has let go of control in Alfa-Laval, Esab, KemaNobel, SAAB Auotmobile, Swedish Match, and partially of Scania and most parts of the Incentive conglomerate and of Diligentia while established control of Gambro, WM-Data and a 
portfolio of smaller firms. The group has also been instrumental in abolishing shares with a 1:1000 voting differential in Electrolux and SKF but not in Ericsson until 2004 when the A-shares were finally converted to a new differential of $1: 10$ as the other controlling owner, Industrivärden, (finally) accepted the negotiated compensation for old A-shares. Instead of a joint voting strength of $+80 \%$ ín Ericsson, they now only control around $40 \%$ of the votes.

The long-run survival of controlling families in Sweden looks as follows. 4 (Wallenberg, Bonnier, Johnson and Söderberg) of the 14 families that established control before 1920 are still exerting control while 6 (Rausing, Kamprad, Olsson, Wallenius, Persson, and Stenbeck) of the 23 families that founded firms between 1920 and 1965 are still significant and active owners today. Other vanished slowly and maintained positions until the 80s: Kempe/Carlgren, Salén, Edstrand, Roos, Malmros, von Kantzow, Throne-Holst, Philipson, Wendt. These families were wellconnected but most likely the entrepreneurial spirit ran out and so did their financial resources. Newer additions have shown much worse survival rates. The addition in recent years of new family controlled firms that have grown large very fast has been very limited indeed, the very old firms still dominate, even if the number of family controlled firms among IPOs had been high; see Holmén and Högfeldt (2004a).

Significant legal restrictions on foreign ownership have been an important ingredient of the Swedish ownership model. Starting with ban on foreigners owning real estate and mines in the $19^{\text {th }}$ century, foreign ownership was in 1916 limited to 20\% of voting rights in Swedish firms owning natural resources. In the 30 s foreign ownership in listed firms was limited to so called unrestricted shares (representing at most $20 \%$ of the voting rights) while restricted shares could only be owned by Swedish individuals and institutions. ${ }^{6}$ There has been a dramatic increase in foreign ownership of listed shares since 1993 when the restrictions on foreign ownership were abolished. Anticipating that direct foreign ownership of equity will be allowed as part of the process to join the EU, many

\footnotetext{
${ }^{6}$ In 1983 the restriction on foreign ownership of natural resources was adjusted to the dual system for foreign ownership of shares in listed firms in the Corporate Purchase Act (Företagsförvärvslagen).
} 
family controlled firms started to use dual-class shares in the 80s; an overwhelming majority of them used it in the early 90 s.

Looking further back at trends, direct ownership of listed shares by Swedish households has decreased from $75 \%$ in 1950 to about $25 \%$ in 1990 while ownership by Swedish institutions increased from about $20 \%$ in 1950 to $70 \%$ in 1990 ; foreign ownership was well below $10 \%$ during this period but is currently around $35 \%$. These types of portfolio investments are primarily in Bshares. The original owners have therefore most frequently managed to remain in control by using dual-class shares more efficiently. But the institutional capital has definitely become much more important in Sweden and has recently, somewhat reluctantly, started to exert responsibility and power as large providers of capital but not necessarily as controlling owners.

Table 6 shows that almost 70 years after the formal legal separation from the banks, the two closed-end funds - Investor and Industrivärden-- are still the major controlling owners of the largest listed firms. Even if the pyramids are shallow the combined effect with dual class shares creates a substantial control multiplier: total equity value of firms controlled by closed-end investment funds (CEIFs) divided by value of capital invested by controlling owners. For example, Panel A shows that in year 2000 the controlling owners' investments in the CEIFs were worth 80 billion SEK, which amounts to 2.6 percent of the market capitalization of the SSE. The total market value of listed firms de facto controlled by the CEIFs (largest fraction of votes) was 1786 billion SEK, which is 57 percent of the market capitalization of 3135 billion SEK (excluding the market value of CEIFs). ${ }^{7}$ The control multiplier was thus 22 (57/2.6) in 2000 and has grown over time.

Panel B shows the dominance of the two most powerful CEIFs-- Investor and Industrivärden - where the pivotal owners controlled almost 50 percent of the market capitalization by investing only two percent of the market capitalization. The control multiplier for the two combined was thus $23 .^{8}$

\footnotetext{
${ }^{7}$ At the end of 2000, 4 (12) of the 10 (20) largest firms (market value equity) in Sweden were controlled by CEIFs .

${ }^{8}$ The dramatic increase in the CEIF control multiplier in 1991 is due to intra group takeovers. Industrivärden acquired Bahco (previously named Promotion), the other CEIF controlled by the SHB group, while Investor acquired another
} 
The firms controlled by CEIFs do not only dominate the stock market capitalization. They are also extremely important for the general economic activity in Sweden. In 2000 CEIF-controlled firms generated 38 percent of the Swedish GDP. ${ }^{9}$ And in 1999 their investments constituted 28 percent of the gross capital formation in the business sector. By controlling a large share of the corporate capital in Sweden, the pyramids' investment decisions thus have significant impact on the overall allocation of economic resources. Even if the separation of ownership and control in pyramid structures is a well-established international phenomenon, the very large control multiplier in CEIFs may thus have wider economic implications in Sweden.

Via Investor the Wallenbergs also exert a significant political influence both externally and within the business community, e.g. by being the controlling owners (together with the government) of the Stockholm Stock Exchange (SSE), and by in effect setting their own standards for listing requirements and for ethical codes-- the Swedish version of self-regulation. After the equity markets were reactivated in the 80 s and firms needed more capital as the size of firms grew rapidly, the two funds' control has in fact increased because of very extensive use of dual-class shares. Overall entrenchment of corporate ownership has increased since other listed firms as well as newly listed IPO firms have also used dual-class shares in an unprecedented way to maintain control; around $60 \%$ of the listed firms use dual-class shares. Despite the very significant increase of institutional capital and foreign capital, corporate ownership is as entrenched as ever in Sweden since the largest firms are still controlled by an old financial nobility of families in the 3-5th generation, and banks but to a much lesser extent by institutions that provide the majority of the capital.

The conflict between private control and increasing capital demands is thus handled in Sweden by strategic pyramiding and more frequent use of dual-class shares that increases the separation between control and ownership over time. The pivotal corporate control of the largest listed firms thus remains in Swedish hands while the capital becomes more institutionalized and

Wallenberg-controlled CEIF: Providentia. The value under control remained roughly the same, but the value of the controlling owners listed investments decreased. The same year Investor also acquired Saab where the Wallenbergs had a large direct ownership. In 1994 Investor also acquired Export-Invest, another CEIF within the Wallenberg sphere.

${ }^{9}$ GDP and capital formation numbers are collected from Statistiska Centralbyrån (SCB, Statistics Sweden) 
international. The rest of the paper is an attempt to explain why this happened and what the longterm consequences are. It is a highly political story!

\section{Social Democracy and Capitalism}

The historical agenda of the Social Democrats had three stages: First, the fight for political democracy (suffrage); then use of parliamentary power to implement social democracy (an egalitarian welfare state) and finally economic democracy when economic decisions within firms are not based on strict private rationality but reflect the wider social interest of the firm's stakeholders and society at large. The electoral victory in 1932 initiated implementation of the social democracy. The existing industrial structure with relatively large scale production in a few export-oriented firms, often with a well-defined controlling owner or a strong manager, suited their vision of the road to economic democracy quite well. They did not envision direct nationalization of industries but a stakeholder form of socialism that was more efficient than pure capitalism because it contained elements of rational planning that would eliminate the waste that irrational, shortsighted markets create like unemployment and volatile investment cycles. But also because the necessary economic changes would be faster and more efficiency-enhancing if they take place in ways that are more socially acceptable for workers. Egalitarianism and economic efficiency were thus not necessarily contradictory concepts.

The ideological motivation was the almost existential conflict built into capitalism between private ownership of capital (firms) and the ever growing social character of production; workers are not only a production factor but also members of society with social needs, and private economic decisions within firms will have a wider and deeper impact on society at large. The immediate needs of the workers within the firm would be protected by their union negotiating with the employer about compensation and working conditions without governmental intervention (except for basic regulation), i.e. the adversarial relations between labor and capital would be respected without board representation of labor. Their more general social interests outside the firm 
(e.g. employment, pension, education, and housing) would be protected via social democratic political initiatives to build a tax-financed public sector that redistributes resources between individuals and families and provides social services and insurance. The overriding objective was however to create a full employment economy by promoting growth-enhancing policies that stimulated labor mobility as well as investments and restructuring within the industrial sector. Higher growth would not only generate higher wages but also increase welfare by financing the public sector.

The Social Democrats' vision of economic growth was large scale production with ever growing firm size as resources are better used within a planned hierarchy than in markets, in particular allocations to large investments and to large scale R\&D are more efficient; see e.g. Wigforss (1980) vol I. To realize the idea of a more efficient, higher stage of capitalism the pivotal factor was to induce capitalists to invest more, particularly in long-term capital-intensive production; a good capitalist is one who fulfills his/her basic economic function of investing. The increasing dependence of very large firms would also make the social character of production more obvious, and thus also the need to let the firm's stakeholders and wider societal concerns affect the private economic decisions within the firm. This was in effect a vision of a corporatist society with capitalistic firms without capitalists as their decision power would be cut back to the decision to invest; capital would remain within the firm as investments financed by retained earnings were heavily tax subsidized. Firms would be run in the interests of society at large and not in the narrow, private economic interests of essentially nominal owners. Or to use the words of Ernst Wigforss, the leading ideologue and minister of finance from 1932 to 1949, social firms without owners. Taming of capitalism did thus not imply immediate takeover of private ownership as long as the capitalists invested.

The existing corporate structure of relatively few but large, export-oriented firms closely affiliated with and often controlled by the major banks actually fitted the corporatist vision very well. Banks are intrinsically relatively more important than individual firms as they are pivotal 
nodes in the network that allocates capital across firms and individuals, which may make it easier for them to assume wider societal concerns. However, perhaps more importantly, being both major lenders and providers of equity capital to the often highly levered firms, the controlling banks in effect acted more like bondholders with focus on long-term survival than as thorough-bred, risktaking capitalists. They are therefore more inclined to adopt a long-term perspective with less focus on myopic profits and more ready to accept social considerations when firing and hiring people. In particular, they are more likely to finance large, capital-intensive investments that are also socially desirable. Such owners are also more conducive to respond to tax-based policies that strongly stimulates re-investment of retained earnings in the large, established firms. ${ }^{10}$

The idea of social firms without owners was part of a greater vision of a socially planned (democratic) economy that consisted of an integrated set of policies. For example, tax-based policies to promote and direct investments, and regulations to channel household savings to politically controlled funds that allocate capital to socially desirable objectives like investment in housing, infrastructure and education. But also programs to stimulate growth by promotion of innovations, labor market mobility and extensive research in cooperation with the leading capitalists and their firms. The pivotal element was to generate a higher overall growth rate by policies that stimulated savings and allocated investments more efficiently by also incorporating wider societal objectives. The higher growth may then be used to finance the social reform agenda. The programs would be implemented by the Social Democrats but in close cooperation with the capitalist. How was it done?

\section{The first step on the road to economic democracy: Cooperation in corporatist spirit}

1938 is a pivotal year for two reasons. First, to avoid political intervention and legislation to regulate the tempestuous labor market relations but also to appease unions that voiced more radical

\footnotetext{
${ }^{10}$ In the 50s Galbraith's book from 1956 - American capitalism: The concept of countervailing power- and later his 1967 book-- The new industrial State-- had a strong influence on the leading social democrats with its blessing of large scale production. He was invited by the PM for a two day conference with leading representatives of the Swedish society.
} 
political demands, SAF (The Swedish Confederation of Employers) initiated talks with LO (The TUC) that resulted in a general accord - Saltsjöbadsavtalet - that regulated their interactions. It contained rules for negations, conflict resolution, procedures for how to fire and layoff workers, and for how to limit the detrimental effects on third parties and society at large. The implicit trade-off in the agreement was that SAF recognized the LO as a full and equal counterparty representing all workers while LO accepted the employers' right to unilaterally direct and assign the workload between workers. The accord had a distinct corporatist character and established a spirit of consensus and cooperation in labor market relations that stressed common economic goals-Saltsjöbadsandan — and lasted for almost 40 years until 1976 when LO abandoned the accord. It was particularly strong after the mid-50s when SAF initiated centralized wage negotiations between the parties (perhaps due to an increased labor shortage).

The second pivotal event in 1938 was the reform of corporate taxes to grant free depreciation allowances for machines and equipment. This system benefited large, profitable and capital-intensive firms as historical profits (retained earnings) determine future investments. Since the rules were very generous also by international standards, the previous hostility towards social democratic policies from leading CEOs of ASEA, Electrolux, LM Ericsson, Separator (Alfa-Laval) and SKF called TBF (The Big Five) subsided even if this political pressure group existed until 1953. Starting in 1958, the corporate tax system allowed accelerated depreciation for machines and equipment ( $\max 40 \%$ of profits before taxes in an investment fund) while at the same time depositing $46 \%$ of the depreciation allowance in an account in the Central Bank that did not pay any interest and could only be used if approved by the bank as part of general business cycle policies.

These two major changes in 1938 made cooperation between labor and capital the norm for interaction in the corporatist society but biased the firms' investment criterion as retained earnings became the major tax-subsidized source of financing. Almost concurrently, the major banks were allowed to transfer the significant corporate assets they held after the crises in the early 30 s to holding companies organized as closed-end investment funds. By making their temporary 
ownership in the aftermath of the crisis permanent, the leading banks became the major owners of the largest listed firms even if formally only at arm's length. These three changes shaped what might be called The Swedish model and had long-run implications for the future political and economic developments.

\section{The second step: The corporatist innovation model}

The social democratic vision of the social firm was a large, capital-intensive firm that invests heavily, particularly in $\mathrm{R} \& \mathrm{D}$, in order to be more productive and to grow larger. The basic idea is that innovations are best developed in and commercially implemented by very large export-oriented firms. Small firms may innovate but are of limited importance and can be appropriated by the larger ones that undertake $R \& D$ in a more rational systematic way and can carry the large fixed costs because of their size. The importance of entrepreneurs who develop innovations commercially by founding new, viable and rapidly growing firms was heavily discounted by the leading Social Democrats as they argued that capitalism had reached a higher and more advanced stage of large scale production and innovation. Entrepreneurship was thus implicitly assumed to be exogenously given despite the fact that the leading Swedish firms were founded not so long ago by innovators who turned entrepreneurs.

In fact the Swedish model has two innovation systems (see Erixon (1997)). In the fundamental system the large, mature firms in engineering and manufacturing produce or acquire new ideas through their international contacts, transmit them to their domestic plants and other firms. Exposure to foreign competition and demanding customers abroad force the export-oriented firms to assimilate and develop new ideas into commercial products. These innovations are not of break-through character that establishes new firms but they rather shape or reshape existing firms to maintain their competitive edge. This innovation system is thus an integrated part of the large export-oriented firms as it both feeds on the international network and is a prerequisite to remain internationally competitive. 
The regulated system of innovations is more domestically oriented and is based on the cooperative interaction between public authorities (not primarily universities) and large domestic firms mainly producing investment goods and advanced products. The authorities may stimulate innovations through public procurements (military orders); technical cooperation with authorities (between Ericsson (telecommunication systems) and Televerket (monopoly operator)); through regulation and setting of standards (housing, energy transmission and consumption, safety and environment) and through tax policies like the free allowance of $\mathrm{R} \& \mathrm{D}$ expenditures; more than $90 \%$ of the R\&D spending in the Swedish manufacturing industry during the postwar period was financed within the firm.

The regulated innovation system has probably been the more important since it amounts to a rather direct form of economic support of the largest firms using the taxpayers' money, and in particular since it was part of "planned" economy with coordinated public policies. For example, behind tariffs and import restrictions, and with support of tax subsidizes for firms to buy trucks and cars, and heavy public investments in the national traffic system, the transportation industry developed very fast during the early post-war period. Using regional subsidizes, SAAB and in particular Volvo integrated backwards and developed an elaborate network of decentralized suppliers; the transportation industry became a very large employer and a significant export industry. The saying that what is good for Volvo is good for Sweden was commonly accepted. But without protection and support of specially designed public policies Sweden would not be the domicile of two (Scania and Volvo) of the three largest manufacturers of heavy trucks in the world. Without the public support from universities (elaborate education of engineers and advanced research), regional subsidizes and large advanced public orders Ericsson would not have become the largest supplier of telecommunication systems in the world. Similar programs were developed for huge investments in energy production and systems, for highways and for housing: The Million Program between1965-1974. 
This cooperation in large scale projects between public authorities and the largest firms had a significant corporatist and somewhat nationalistic flavor as the unions actively participated and the coordinated efforts were heralded as part of the national project to build the country in a spirit of strong consensus under Social Democratic leadership. It is striking how strong the coordination and integration of the policies (industrial, regional, tax, and labor market policies) were towards a common goal of developing a more rational, social economy that satisfied the peoples' needs through significant interventionism, in particular by directing and coordinating large scale investments with significant externalities.

The very large, public investments projects were financed by taxes but also by channeling of savings to public pension fund (The ATP-system with 3 original AP-funds; later supplemented by a $4^{\text {th }}$ fund that also invested in equity) that invested in public bonds. Since the equity markets in effect were closed down until the early 80 s and the Central Bank and the Ministry of Finance controlled the capital flows in the financial system, banks and insurance companies were forced to invest very heavily in public bonds, in particular to finance the very large housing program. To channel household savings to collective funds and direct their investments was a very important part of the policies to implement a social democracy and use political power to direct investments. These policies in effect made the large listed firms even more dependent on retained earnings to finance investments; the volume of bank loans was regulated and capped while the equity markets were not operational.

\section{The third step: The labor market model}

An important part of the growth policies was the so called active labor market policies initiated by LO in 1951: The Rehn-Meidner model (see Hedborg and Meidner (1984) and Korpi (1978)). To sustain a full-employment economy that grows without inflation that idea was to support reallocation of resources and employment away from industries that are not internationally competitive to more productive industries with sustainable growth opportunities. Through 
solidaristic wage policies that compress the wage differential at a high average level that maintain the international competitiveness of the export-oriented sector, the overall productivity would increase by speeding up the closing down of firms in less productive industries while in effect induce firms in more competitive industries to become more efficient by investing in more capitalintensive technologies. The model tends to generate excess profits in the most competitive firms as they pay relatively low wages. Combined with labor market policies that retrain workers and stimulate their geographic and occupational mobility by compensating them for loss of income and extra costs when relocating, the model enhances the dynamic efficiency in the economy without causing too high inflationary pressure. The public sector would thus support and pay for the higher labor mobility. The model combines an egalitarian ambition with support for reinforced dynamic restructuring in order to maintain competitiveness, a higher growth rate and higher wages.

When the negative social consequences of the higher mobility (regional unemployment, disparate regional economic development and unemployment; increasing geographic concentration of jobs to the largest firms' plants) became too costly politically in the early $70 \mathrm{~s}$, the labor market policies changed from encouraging mobility to support lock-in of employees with the current employer as the new labor market legislation focused on job tenure. At the same time the overall unemployment rate tended to increase because of the stiffer international competition.

\section{The result: The Swedish model}

The Social Democrats accepted the private control of the largest firms while the leading capitalists accepted their political dominance. Based on mutual acceptance, an elaborate cooperation in corporatist spirit developed around large infrastructural and industrial projects that benefited the largest export-oriented firms in engineering and manufacturing. Tax-based policies to stimulate a high investment level, particularly in the transnational firms, by subsidizing investments in machinery and buildings and $\mathrm{R} \& \mathrm{D}$, and give priority to retained earnings and bank loans as the major sources for financing - institutionalized saving in collective funds. Labor market relations 
are peaceful and cooperative but with respect for adversarial interests; no co-determination. The policies stimulated and supported a high growth rate and propagated the established large-scale industrial firms with concentrated private ownership but deliberately ignored the formation of new firms and the importance of small firms: a dynamic but aging social economy with a large public sector.

\section{More radical policies to implement economic democracy}

Profound political, social and economic changes designate the years around 1970 as the defining moment for the Swedish model; what might be termed its Golden Age came to an end and its negative effects became all too apparent in a very short space of time. In response to very fierce critique against the political incumbency, both from within and from outside the labor movement, LO and SAP became more radical by proposing strongly egalitarian policies with more redistribution of incomes and opportunities via the public sector that grew very fast during the 70s, and resulted in the highest taxes in the world. ${ }^{11}$ More than half of the average income was paid in taxes but a significant part was directly paid back to the households through redistribution programs, in particular to families with children, students and pensioners, but also indirectly as subsidized consumption. At the party congress in 1975 Olof Palme initiated the third stage of the historical agenda: economic democracy. The timing could hardly have been worse as e.g. the Bretton Woods system-- the anchor of the strongly interventionist economic policies with control over capital flows - was collapsing, the oil crises had triggered the deepest economic crises since the 30s; the new constitution adopted in 1973 used strictly proportional elections (which tend to and did breed instable minority governments) and SAP was about to lose the 1976 election after 44 years in power.

\footnotetext{
${ }^{11}$ In retrospect the perhaps most important event was the long, bitter and very politicized, illegal strike in the North in 1969 against poor and unequal working conditions in the mines of the State run corporation LKAB. It triggered a fierce debate with uncompromising critique against the political incumbency as it made the inequalities visible (see Korpi (1978) and Hedborg and Meidner (1984)).
} 
The basic principle of non-intervention by the government in labor market relations was abandoned in 1974 with The Employment Security Act (LAS) that was written and enacted in response to direct demands from LO. It provides the employees with an elaborate protection against dismissal and application of a strict last in - first out principle (LIFO); the only two legal grounds for dismissal are gross misconduct and redundancies. The 1976 Codetermination Act granted labor union representatives (strict minority) board representation. The laws were designed with the conditions of the largest firms in mind as the needs and demands of small firms for more flexible adjustment were ignored. Since tenure to the current employer becomes more important for job security than actual skills and effort with the LIFO-principle, the costs of dynamic mismatches increases, both in the general labor market and within the firms as workers de facto become more locked-in with firms. To alleviate the higher costs of LAS for small firms, new and more flexible rules were enacted in $1997 . .^{12}$

But the most radical proposal was the 1976 decision by the LO congress to implement Ernst Wigforss' vision of social firms without owners by a gradual transfer of ownership of all firms with more than 50 employees to wage-earner funds with trade union and other stakeholder representatives collectively exercising the funds' voting and other ownership rights. The actual transfer of shares would occur by private placements to the funds corresponding to $20 \%$ of the firm's annual profit. The more profitable the firm is, the faster the transfer of control— at a profit rate of $10 \%$ if would take 35 years for a fund to establish a majority control. Consistent with the established line of ideas, the fund's capital would stay within the firm and not be reallocated. The combined effect of the labor market laws and wage earner funds would thus be an even stronger lock-in of both capital and labor within firms.

\footnotetext{
${ }^{12}$ For example, by the use of prearranged temporary employment contracts all firms have the unconditional right to employ up to 5 persons for a maximum of one year; the possibility for local collective contracts to replace the stipulations in the law and sidestep the FIFO principle in case of dismissal; annul the right of reemployment for dismissed workers and to extend the temporary employment beyond a year. In case of redundancies, firms with no more than 10 employees are allowed to except 2 workers from the FIFO principle by a new law in 2001.
} 
The proposal had the lukewarm support of the SAP leadership and was the catalyst that united all members and organizations to the right of the labor movement in the most vociferous protests ever. A watered-down and rather tame version was enacted in 1984 after the Social Democrats returned to power in 1982, but was abolished by the Center-Right government in 1992 and not reintroduced by subsequent Social Democratic governments. ${ }^{13}$ The controversy over wage earner funds is the only time that private ownership has been really questioned. The debate has been silent since then.

\section{The orthogonal trajectory away from economic democracy}

It is fair to assume that outside observers of the Swedish society around 1980 would have predicted a bumpy road ahead to economic democracy with more interventionism and stronger political control over the economy. But the real historical irony is that the actual trajectory chosen by the Social Democrats when returning to power was orthogonal to the conjectured one as it entailed a radical break with past policies; e.g. far-reaching deregulation of the banking system, dismantling of capital flow controls, privatization of state-owned firms and policies that promoted market competitiveness, and reactivation of equity markets that were liberalized with unrestricted foreign ownership of shares. The chosen road led to more market economy, not to more socialism.

A similar radical across the board break with the old did also happen in France with a Socialist government (see Helleiner (1994). Given the centralist nature of both Swedish and French political governance structures, the turnaround behavior is broadly consistent with Rajan and Zingales' (2003 a and b) political theory of incumbency. ${ }^{14}$ But perhaps a more direct interpretation of the Swedish case is that it shows the profound pragmatic character of an encompassing party that has been heavily entrenched for decades and almost inseparable from the state bureaucracy: to win elections in order to exercise power is the primary objective. But to win elections the economy has

\footnotetext{
${ }^{13}$ The 5 wage-earner funds were financed by a $0.2 \%$ pay-roll tax and a $20 \%$ tax on real profits above SEK 1 million during 7 years. When abolished the funds' capital was distributed to research and venture capital funds to promote new firms.

${ }^{14}$ Henreksson and Jakobsson (2003a and b) presents an alternative interpretation that emphasizes the break in policies but does not provide a consistent explanation as they seem to argue that the threat form Socialism is as unrelenting as ever.
} 
to be in order. The very radical change of policies was perceived as necessary to get the economy in order and promote growth.

\section{Necessary condition for the Swedish model of corporate ownership: Organized labor and capital}

One important part of the Swedish model of corporate ownership is that it presupposed the existence of two identifiable, well-organized parties — labor and capital — that both had a political and a trade-based, corporative representation. At one level it is of course trivial to characterize the society as corporatist but why did it become corporatist and why was it so important, in particular for the Social Democrats? ${ }^{15}$ My answer pinpoints both external (exogenous) and ideological factors. The fact that the industrial production was comparatively capital intensive and organized in relatively few, large and geographically concentrated units in firms controlled by families and part of networks around the leading banks facilitated organization of both employers and employees. So did the smallness of the culturally homogenous society, and that industrialization came relatively late but was then very fast. The other crucial exogenous factor was the strongly export-oriented character of the largest firms which made both capital and labor heavily dependent on the business cycles and fostered a sense of fighting the economic elements together. For example, after the deep crisis in the early 20s, the strategies of both SAP and LO changed to become less adversarial and more focused on employment and higher wages, which during the long, unprecedented expansion since the 1890 s had been taken for granted.

The ideological factor is the idea that labor and capital are the two natural adversaries in a capitalistic economy but that capitalists are crucial for the development of an advanced social democracy because of their strategic control over investments and thereby of the growth in the private sector. It was thus not inconsistent with the Social Democratic ideology to accept and respect (at least for the time being) private ownership, and even reinforce the entrenchment of welldefined private owners by political support for the use of dual-class shares and pyramiding. In

\footnotetext{
${ }^{15}$ Reiter (2003) argues that the crucial importance of Saltsjöbadsavtalet 1938 was that it gave the Social Democratic Party an identifiable counter-party in the countries export-oriented industrialization and the construction of the welfare state but does not provide any arguments or theory that explains why.
} 
exchange the capitalist did not move their capital or refuse to invest but accepted the political supremacy, in particular since it involved an elaborate and profitable collaboration with the government and the unions. The objective of social firms without owners could thus be implemented (at least partially) via negotiations between the firms' two major stakeholders with the (often passive) support of the government (state). The fact that both the workers and the leading capitalists already were united in encompassing, national and centralized organizations that stressed overriding goals facilitated consensus-based outcomes, which fitted the ideological view that society is progressively changed via many small and peaceful steps.

This combination of exogenous and ideological factors does not fit the political (nonideological) theory of Pagano and Volpin (2004) of a corporatist political equilibrium where low investor protection that benefits controlling owners is exchanged for high employment protection for labor. This outcome is more likely under a proportional voting system as it fosters the formation of homogeneous blocks of voters, in particular if also the wealth distribution is unequal or the production technology has low capital-intensity. ${ }^{16}$ The listed firms in Sweden did, however, (on average) use relatively capital-intensive technologies and were primarily dependent on banks for their financing, not on equity financing as their theory seems to suggest. The strong dependence on a relation-based banking system thus implies that neither an unequal wealth distribution nor lowcapital-intensity technologies are necessary conditions. ${ }^{17}$ Interestingly, only since the Swedish voting system became fully proportional in 1973 have governments without participation of the Social Democratic Party been formed for the first time since 1932.

The one-sided emphasis on equity markets, in particular on the primary function, in theories of political economy of corporate ownership (governance) is difficult to reconcile with the limited dependence of such markets in Continental Europe for most of the previous century. Ownership is

\footnotetext{
${ }^{16}$ The intuition behind this result is that proportional voting pushes political parties to cater more to the preferences of social groups with homogenous preferences, that is, entrepreneurs and employees. This is because under this voting rule the additional mass of voters that can be attracted by shifting a party's platform is greater if the shift favors a homogenous constituency; see Pagano and Volpin (2004).

${ }^{17}$ In a more literal sense it is also difficult to imagine that shareholder minority protection should be on the top of the minds of controlling owners and that workers should have any reason to develop preferences about such protection. In particular since they did not own any shares and stock markets were closed down at the time when corporatism reigned.
} 
not more concentrated there because of weaker legal protection of minority shareholders as the theory seems to presuppose (see also Burkart et al (2003)) but primarily because of political support for use of mechanisms to separate votes from capital (dual-class shares, cross-shareholdings and pyramiding); see Holmén and Högfeldt (2004a). Politically motivated concessions, both to the government and to the workers, are easier to obtain when firms have a well-defined private owner in control as they are visible in the public arena. It is therefore not surprising that concentrated private ownership seems to cluster with well-organized labor unions and formation of major parties along the left-right spectrum. Rather than focusing on formal minority protection, it seems more natural to pinpoint the political support for concentrated ownership built on separation of ownership from control and how this systematically affects corporate financing and worker protection.

I sum up this section by answering one of my main questions: Why did the Social Democrats not only accept but de facto supported that control of the large, listed firms and of the pivotal banks, remained in private hands? A possible and plausible answer has three parts. First, the party's ideologically and economically pivotal objective to influence or control the large listed firms' investment behavior could be achieved through means that did not assume the eclipse of private ownership. Second, since old family fortunes remained within the firms as working capital and became foundations (institutions) because of the tax policies, the private capital in effect became more social and institutionalized, in particular the bank capital; the remaining "private" character of capital was not a primary problem. Moreover, since formation of large, private fortunes in newly founded firms via equity financing was limited and controlled by tax policies and regulations, the wealth distribution did not threaten to become too dispersed.

Third, implementation of the Social Democrats' social agenda did not necessitate a takeover of control of large listed private firms, but could be realized through reforms and policies that redistribute resources and opportunities via the public sector with strong and persistent electoral support. While their more radical agenda for economic democracy was more ideological and abstract and did not generate enough popular support. Besides more tactical considerations, the 
heavy and unprecedented entrenchment of the party in general and the fact that individual careers are closely tied to being in control of the public bureaucracy in particular, de facto narrowed the primary objective to win elections to remain in power and run the economy in a competent and stable way to finance reforms.

\section{Corporate Ownership and Development of Financial Markets}

Why did not corporate ownership in Sweden separate widely as in the Anglo-Saxon countries? The leading answer in the literature would be that it is because of weak formal minority protection (see e.g. La Porta et al (2000) and Burkart et al (2003)). Good protection encourages both outsiders to invest and founding families to sell out a larger fraction in an IPO since formal rules limit extraction of pecuniary benefits by management when the firm becomes widely held; both factors stimulate development of advanced financial markets. Lower protection thus causes founders to maintain a larger fraction of shares to avoid being exploited, which predicts a negative relation between formal minority protection on the one hand, and ownership concentration and size of (pecuniary) private benefits of controlling owners, respectively, on the other. But this line of reasoning does not square well with the history and politics of corporate ownership in Sweden for several reasons.

The empirical estimates of Dyck and Zingales (2004) suggest that contrary to the predictions, the size of private benefits in Sweden are of about the same size as in the Anglo-Saxon countries that are perceived to have a better formal (legal) minority protection. In particular, there is no positive relationship between ownership concentration and size of private benefits or a negative relation with the level of minority protection (see Holmén and Högfeldt (2004a)). Inconsistent with the leading theory, the only legal regime dummy that is significant is the negative coefficient (lower private benefits) for Scandinavian origin. Other behavioral factors that are related to the culture and norms of the society like degree of tax compliance, level of corruption, openness, and crime rates eliminate the explanatory power of legal regimes and of level of minority protection (see Dyck and Zingales (2004)). Stock market capitalization in relation to GDP, number of listed firms per million 
inhabitants, frequency of IPOs and household frequency of equity ownership (around 55-60\%) are if not higher at least comparable to the Anglo-Saxon countries and higher than for Continental Europe (see Holmén and Högfeldt (2004a)). The potential for transfer of corporate assets to the controlling is perhaps largest in pyramiding, but unlike Bertrand et al (2002) for Indian pyramids, Holmén and Högfeldt (2004b) find no evidence of tunneling in Swedish pyramids.

Lack of minority protection did not hinder the development of active financial markets before WW1 (see Rajan and Zingales (2003a). It was neither a prerequisite for the stock market boom in recent decades as the protection was improved in the early $90 \mathrm{~s}$ after public scandals involving self-dealings, particularly in management controlled firms with cross-shareholdings. The differences in formal minority protection between advanced countries seem too small to explain the very significant discrepancies in ownership concentration; see also Roe (2002a and b).

Implicitly, the leading explanation seems to assume that the size of private benefits of control is larger if the firm becomes listed than if it remains privately held because of the pecuniary extraction from minority shareholders. But the two most successful firms in Sweden founded after WWII-- IKEA (founded by Ingvar Kamprad) and Tetra Laval (the Rausing family)-- have both (aggressively) avoided going public with the explicit argument that their private value of control would be diluted. Both because of the listing (information and transparency) requirements, and since their long-run strategy (patiently building an empire) may be compromised by the perceived myopic character of the stock market. The third most successful firm, H\&M (international chain of clothing stores founded by Erling Persson) went public in the $70 \mathrm{~s}$ in order to finance its future growth, in particular its international expansion. But since H\&M has consistently generated high enough profits to fully finance its investments by retained earnings, Stefan Persson, the head of the family and COB (former CEO), has officially announced that the family regrets the listing; it would have been better to stay private. Private benefits of control may thus have less to do with pecuniary extraction of minority shareholders than with the value of being in control (power) per se, which is maximized when staying fully private. Since a public listing dilutes private benefits of control, a 
family-controlled firm goes public only when it needs new capital. More generally, Holmén and Högfeldt (2004a) find that Swedish IPO firms in general but in particular family firms have a strong preference for maintained control, and their behavior is consistent with the control theories (see Bebchuk (1999) and Bebchuk et al (1999)).

\section{Roe's political theory}

Mark Roe's alternative, political theory that ownership does not separate widely in Continental Europe since it is not politically and socially acceptable in the social democracies is summarized in his Clarendon Lectures (Roe (2002a)):

It (ownership; my remark) is concentrated in no small measure because the delicate threads that tie managers to shareholders in the public firm fray easily in common political environments, such as those in the Continental European social democracies. Social democracies press managers to stabilize employment, to forego some profit-maximizing risks with the firm, and to use up capital in place rather than downsize when markets no longer are aligned with the firm's production capabilities. Since managers must have discretion in the public firm, how they use that discretion is crucial to stockholders, and social democratic pressures induce managers to stray further than otherwise from their shareholders' profit-maximizing goals. A crucial political prerequisite to the rise of public firm in the Unites States is the weakness of social democratic pressures on the American business firm.

The dual side of this compelling set of arguments is thus that social democracies in Roe's wider sense presupposes concentrated corporate ownership but will be less efficient as necessary changes will be delayed or not take place. The first implication is generally in line with my arguments but the second one does not fit the history and politics of corporate ownership in Sweden, perhaps the most quintessential social democratic society, very well. Roe's arguments do for example not recognize the pivotal effect in a small open economy of the international, competitive exposure on labor market relations and conditions within the firm. Being determined by outside conditions, it is perceived as an objective, exogenous factor that defines the necessary adjustments and limits the set of possible actions in order to remain competitive and being paid a higher wage in the current or in another job. As an encompassing union, the well-established tradition within the LO has been not to fight changes motivated by rational economic arguments but to accept and actually facilitate them in order for the whole economy to maintain its competitiveness and growth. In fact, the general economic policy, in particular the labor market 
policies, that the Social Democrats pursued with the active backing of the LO were at least until the 70s very growth-oriented as they stimulated structural changes and rationalizations, promoted labor mobility and provided ambitious retraining and educational programs for the unemployed. Local unions may voice protest but are not known to obstruct or aggressively fight back if negotiations about lay-offs and close-downs are done in an orderly manner. Looking through the Swedish lens, Roe ignores the crucial importance of a public sector that provides an outside protection via insurance, education and benefit programs that assuages the effects of hardships of unemployment, which seems to facilitate rather than obstruct necessary economic changes.

Despite corporatist tendencies and a spirit of cooperation, the adversarial interests of labor and capital have not been mixed and diluted by co-determination since unions did not get legal rights to elect board representatives until the $70 \mathrm{~s}$; it is a strict minority representation; there are no dual boards and unions have no right to veto a firm's decisions. Unlike in Germany, codetermination was not designed to appease aggressive unions and to fight social and political instability. Moreover, the general rule has been that politicians should not intervene but to let the representatives of labor and capital settle disputes and other matters by negotiations. '

Overall, Mark Roe paints a picture in too stark colors that exaggerates the differences between Continental Europe and the U.S. by implying that necessary economic adjustments will not be efficiently implemented in social democracies. ${ }^{18}$ The Swedish experience suggests that efficiency enhancing changes will be undertaken but in a different and more orderly, fair manner, perhaps somewhat delayed due to negotiations but often with more far-reaching consequences when they occur. ${ }^{19}$ The effect of international exposure, a large welfare sector and of different labor

\footnotetext{
${ }^{18}$ Roe's arguments presuppose that shareholder value maximization has consistently been the single, hard objective in the U.S. while the firm's objective has been diluted by stakeholder concerns in Europe. A reasonable interpretation is that because of primarily political reasons maximization of shareholder value has been accepted only in certain time periods in the U.S. but not uniformly, and that the importance of stakeholder value in Europe has also varied substantially with the political tides. Implicit in Mark Roe's theory about the negative effects of social democracy is also the idea that the relation between labor and management is more adversarial than between labor and controlling owners. If anything the Swedish experience however seems to suggest that the union representatives are more close to the management and that the relations are based on consensus and trust as long as the firm pursues a reliable, long-term strategy.

${ }^{19}$ An illustrative example is the dramatic down-sizing of Ericsson in recent years from 110000 employees worldwide to less than 50 000. A significant fraction of the employees worked in Sweden but very few if any protest were voiced as it
} 
market institutions (encompassing, well organized unions) and ownership structures lead to outcomes that differ perhaps more in form than in substance. The more negative, institutional aspects of the Scandinavian model are the significant lock-in effects of both labor (e.g. strict application of the last in first out rule) and capital within the old, established firms that will be stable and relatively efficient while the addition of new growing firms will be hampered.

\section{An alternative political theory why ownership does not separate widely}

My analysis of the history of Swedish corporate ownership, however, suggests another political theory why ownership does not separate widely: listed firms do not have to disperse ownership and dilute private benefits of control in order to raise new capital since their dependence of the equity market is limited because of political decisions and institutional factors. This is particularly true for the largest listed firms with well-established networks. The focus is on the equity markets' primary function — provision of capital — and its political sensitivity; not on liquidity provision. The basic idea is that political decisions will determine how dependent firms are on external financing: if capital for investments can be supplied primarily through retained earnings, by borrowing in banks or by infusion of private capital, firms have no immediate need to go through the strictures of equity offers and place a larger fraction of shares in a wider group of investors and dilute private benefits of control in the process.

My political theory of corporate financing starts with the assumption that corporate control based on separation of control from ownership via mechanisms to separate votes form capital like dual-class shares and pyramiding presupposes political support to be socially acceptable. In the Swedish case, the political legitimacy of entrenched private ownership is traded-off against that the implicit guarantee that the largest listed firms do not migrate and that they continue to invest, thereby generating economic resources to finance the political reform agenda. The separation of control from ownership has however a profound effect on corporate financing as it drives a

was done in an orderly, negotiated way. The unions did not obstruct but helped to accommodate the changes as they were perceived as necessary in order for Ericsson to survive in the long run. 
significant wedge between the costs of internal and external capital. New external shareholders demand compensation (discounts) for the agency costs inherent in the separation, which makes external equity more expensive. Shareholders seem to attach significant discounts to privately controlled firms using dual-class shares (10-15\%) and to pyramid holding companies $(25-30 \%)$ to separate votes from capital; see Holmén and Högfeldt (2004b). But internal capital is relatively inexpensive for the controlling owners since they have access to all of the firm's cash flows via a small (less than proportional) capital investment.

The wedge caused by the separation of control from ownership therefore generates an enhanced (political) pecking order of financing: Strong reliance on retained earnings and borrowing but avoidance of equity issues, in particular of large public offers as they would dilute control and also be extra costly due to the discounts to new outside shareholders; see Holmén and Högfeldt (2004b). The pecking order is enhanced since it is caused by agency costs inherent to the ownership structure and not primarily by asymmetric information costs, and since it predicts the absence or strong avoidance of public offers; see Högfeldt and Oborenko (2004).This is the key mechanism that explains why firms in countries with prevalent use of dual-class shares and pyramiding like Sweden have more concentrated ownership but are also much less dependent on the primary equity markets and why they do not need to disperse ownership.

The connection between the politics of corporate ownership and financing is particularly conspicuous in regulation of banks' ownership of equity since the 1930s. When the Swedish version of the Glass-Steagal Act was enacted in 1934, commercial banks were no longer allowed to directly own shares in other firms (a right granted them in 1911 because of the pivotal support from the Social Democrats). Reflecting the strong political and economic interests of leading bankers but with support of the Social Democrats, banks were, however, a few years later allowed to transfer their portfolios of controlling interests to holding companies that were organized as closed-end investment funds (CEIFs) and distribute the funds' shares to the banks' existing shareholders. The controlling owners of the commercial banks at the apex of the pyramid thus controlled the largest 
firms at the bottom via CEIFs at the intermediary level that were listed. Since pyramiding was combined with use of dual-class shares the separation between votes and capital was multiplicative.

The new laws in effect made two dominating banks (SEB and Svenska Handelsbanken) the controlling owners of the largest listed firms, and bank loans the major way to finance the firms' investments besides retained earnings, in particular in the decades when the equity markets were dormant. Corporate control was therefore via political decisions directly linked to the control over intermediated capital, which tend to make equity financing much less likely. Unlike in the US, the pyramids were politically supported via the tax system: inter-corporate dividends as well as reinvested capital gains were de facto tax-exempt; see Holmén and Högfeldt (2004b). Since this preferential tax treatment is pivotal for the existence of pyramids (see Morck (2003)), it is the critical element in the Social Democrats' consistent support of the very heavy entrenched private ownership of the largest listed firms in Sweden. It is perhaps also the very reason why capital did not migrate.

More generally, since the Social Democrats for ideological reasons focused on the largest established firms and supported both retained earnings via tax benefits and a relation-based banking system, the two major ways to finance investments both had strong political support. They were also in general very skeptical towards the turbulent equity markets that are conducive to economic and social changes, which is antithetical to their political ambitions to provide stability and social reforms in an orderly, planned manner. But for egalitarian reasons they were, and still are, even more skeptical towards the equity markets' primary function. The combination of entrepreneurship and equity financing will facilitate creation of large private fortunes and break the social status quo, i.e. limit the possibilities for social control and for redistribution. Since a well functioning primary market will widen the income distribution but in particular the distribution of wealth and ownership of assets, new equity issues have consistently been disfavored by a tax disadvantage. Reactive financing via retained earnings that benefits incumbent owners by locking-in the capital in the existing firms was preferred to a more proactive and aggressive financing mode via the primary 
equity market that is more likely to implement faster and more drastic changes that are likely to challenge the incumbents' power. This outcome is also the most likely since the new entrepreneurs and firms lack political power while the well-organized incumbents are united by common interests and have political voice.

As long as this closely integrated system of ownership and financing is stable, the firms do not need to raise substantial amounts of new capital from the equity markets. And when firms were highly levered in the 70s and needed more equity capital as both profits and credits were squeezed, and more restructuring takeovers occurred, there was strong political support for the incumbent (often capital-constrained) owners to use of dual-class shares to separate votes from capital contribution in order to maintain control also after issues of equity. ${ }^{20}$ Hence, for a combination of political and institutional reasons, ownership does not separate widely since listed firms are not directly dependent on equity markets to finance their investments.

My alternative political theory of corporate financing has several testable implications. The first one is that the very entrenched and relation-based banking system will block the development of arm's length markets for corporate bonds; if they exist they will not be well developed. Hence, it should not come as a surprise that there are no domestic corporate bond markets in Sweden and that the largest listed firms use the international bond markets but only to a limited extent.

The second prediction of the theory is that the volume of IPOs and SEOs on average should be very small. Fig 4 shows that the annual volume (2002 prices) of new equity and bond issues on average corresponds to about $10 \%$ of gross domestic capital formation before 1931 but averages only about $1 \%$ since then. The peak in 1917-1918 is a result of the speculative war economy fuelled by excessive buying of new issues by the highly levered and bank-affiliated Issuing Companies

\footnotetext{
${ }^{20}$ The legislators' motivation for use of dual-class shares in the new corporate law (Proposition 1997/98: 99 p 120- my translation) illustrates the political support: The use of shares with different voting rights has a long tradition in Swedish law. Dual-class shares are very common among listed companies in Sweden. The dual-class share system has significant advantages. It makes it possible (facilitates) to have a strong and stable ownership function even in very large companies. Thereby creating the necessary conditions for an efficient management as well as for the long-term planning of the firm's activities. Shares with different voting rights also facilitate for growing companies to raise new capital without the original owners losing control. There is no evidence that the dual-class share system has caused any noticeable negative effects...Dual-class shares can significantly promote the efficiency and development of individual firms as well as of the business sector in general.
} 
before they were forced to close down after the deep financial crises in the early 20s (Fritz (1990) and Östlind (1944)). ${ }^{21}$ During 1927-1929 Ivar Kreuger capitalized heavily on the exuberant market sentiments by issuing equity and, in particular, debentures (unsecured bonds) both domestically and internationally to save his highly levered and very opaque empire before it collapsed after he shot himself in Paris in 1932 and triggered the worst financial crises in Sweden.

The more recent peak in 1992 around 5\% is the result of extremely low investments due to very high interest rates in the wake of the second worst financial crises when a speculative real estate bubble busted. It was fuelled by excessive credit expansion by the recently deregulated banks. The large volume in 1999 is, of course, due to a record number of IT-related IPOs, particularly related to mobile internet and IT-based services. For comparative purposes, the table does not include the 30 Billion SEK rights issue in 2002 by the financially distressed Ericsson since it is the largest SEO ever. It is particularly interesting to note that this single issue corresponds to $13 \%$ of the total volume of all SEOs (2002 prices) during the last 100 years; 25\% of all SEOs since 1970 and $40 \%$ of all SEOs during the exuberant 90 s (about 10 billion dollars). The listed firms' dependence on the equity markets for new capital has thus been very limited indeed in Sweden.

Because of the strong preference for control, in particular among family firms, a third implication is that dual-class shares should be used very frequently and that SEOs should follow a specific pecking ordering ranked by the extent to which they dilute control: first rights issues, then private placements followed by directed issues (stock financed acquisitions) and finally public offers that are strongly avoided. Moreover, the issues should be relatively small and only offer low voting B-shares. Rights issues should have the largest size since they dilute control the least. The empirical evidence from 233 IPOs between 1980 and 1997 in Holmén and Högfeldt (2004a) and from Swedish SEOs since 1984 in Högfeldt and Oborenko (2004) are consistent with this implication since almost $90 \%$ of the privately controlled IPO firms use dual-class shares and there is a well-defined pecking order of SEOs. In particular, the amounts raised are very small and rights

\footnotetext{
${ }^{21}$ The SEO volume in 1917-1918 corresponds to about $2.5 \%$ of the total stock market value while the volume in $1927-$ 1929 is about $7 \%$ of the market cap.
} 
issues are by far the largest. The fastest growing IPO firms are controlled by the founder/entrepreneur and finance their expansion by rights issues, normally within 18 months after the listing. ${ }^{22}$

It is particularly interesting to observe the absence of public offers, which are both the most common and the largest offers in the U.S. but infrequently used outside the Anglo-Saxon countries. Relatively large public offers are especially important in the financing of newly founded firms that grow really fast (gazelles). But they are also instrumental to disperse ownership widely at and after the IPO. The very infrequent use of public offers may thus explain both why ownership does not disperse widely and why very few young firms grow to become really large in Sweden. To understand why public offers are uncommon in say Civil Law countries may also explain why financial markets in general and primary equity markets in particular are less developed there. ${ }^{23}$ My theory suggests that because of the politically supported control structure combined with the strong preference for maintained private control, public offers are last in the enhanced pecking ordering since they by their larger size dilute control the most and are most costly because of the required discounts to new shareholders.

More generally, my theory predicts that the following stylized facts about the corporate system cluster: (i) concentrated ownership because of extensive use of devices to separate votes form capital; (ii) secondary markets relatively well-developed if dual-class share are frequently used (B-shares provide liquidity) but primary markets particularly politically vulnerable and underdeveloped; (iii) equity financing of investments far less important than borrowing and use of retained earnings (small volume of IPOs and SEOs) and limited market timing; (iv) pecking order also of SEOs: rights issues (largest) and private placements most frequent while public offers are absent or exceptionally few; (iv) very few young firms grow fast to become really large; (v)

\footnotetext{
${ }^{22}$ If the founders relinquish control, they do so by selling their control block before the IPO, but keep the block intact both at the IPO and afterwards until they sell it. Family-controlled firms often finance relatively small acquisitions by issuing B-shares (see Holmén and Högfeldt (2004b) and Högfeldt and Oborenko (2004))).

${ }^{23}$ Even if trading volumes and market caps are less developed than in the Anglo-Saxon countries because of the extensive use of dual-class shares, the liquidity provided by trading of B-shares may still be large: The number of IPOs is not necessarily small since dual-class shares facilitate maintained family control after the IPO and stock financed acquisitions.
} 
undeveloped markets for corporate bonds (due to the strong relation-based banking system) and (vi) relatively equal distribution of wealth and incomes. Because the separation of ownership from control drives a wedge between the costs of internal and external capital, my theory predicts that firms controlled by pyramids or via extensive use of dual-class shares will have higher investmentcash flow sensitivities; see Holmén and Högfeldt (2004b) for supporting empirical evidence.

The reasons why ownership did not separate widely in Sweden are thus according to my theory profoundly political: Use of dual-class shares and pyramiding, which are politically supported, drives a wedge between the costs of internal and external capital that causes an enhanced (political) pecking order of corporate financing. The political support for separation of control from ownership and for non-equity financing benefit established firms and in effect align the interests of the incumbent political power with incumbent capital (in particular the leading banks) as corporate control is maintained and actually reinforced (despite increasing needs for new capital) while formation and growth of new firms by equity financing was effectively disfavored for egalitarian reasons.

\section{A Critical Evaluation of the Swedish Model of Corporate Ownership}

At this point it is convenient to oversimplify and pinpoint three constituent parts of the Swedish model of corporate ownership. The first is the primarily exogenous character of production: capitalintensive, large scale, export-oriented production (raw materials, manufacturing and engineering) by relatively few large, transnational and privately controlled firms. The second is the changing international market conditions due to political, economic (competition) and technological factors. The final is the endogenous effects of prolonged social democratic policies. We focus on the longrun economic effects by looking at the impact of three major Social Democratic policies: (i) Political support for a relation-based banking system and control of the largest listed firms via bankcontrolled closed-end investment funds. (ii) Political support for dual-class shares and other devices to separate votes and capital in order to facilitate maintained private control with well-defined owners despite increasing capital needs and institutionalization of ownership. (iii) Consistent 
political focus on the largest listed firms and strong preference for retained earnings and bank loans as the major ways to finance investment while in particular disfavoring of equity financing and equity markets in general. These policies jointly create the foundation for the enhanced political pecking order of financing and have three major long-run effects.

Overinvestment by large firms in old industries and underinvestment of new firms in growing industries, biased distribution of firm size and age, and lower overall growth

The strong dependence on retained earnings and debt in the enhanced pecking order, reinforced by the preferential tax treatment, implies that firms' investment criterion has been systematically biased since past profits to a significant degree influence or determine the allocation of investments, not expected future profits. ${ }^{24}$ This benefits firms in old established and capital-intensive industries with large real assets that have consistently been profitable and are part of a leading bank's network. But the policies disfavor young firms in new lines of business based on human capital and services with strong growth potential and in need of risk capital. Since incumbent firms have access to relative inexpensive internal capital while new firms are hampered since they use the primary equity markets only to a limited extent, the biased investment criterion is likely to create systematic under- and overinvestment problems that tend to have a negative effect on the overall growth in the economy. The largest firms that will tend to invest too much are in mature industries with lower future growth potential while the new and smaller firms tend to invest too little and are likely to be in lines of business with higher growth potential. These effects are reinforced by the fact that IPO firms for control reasons are not inclined to use large public offers to grow fast and since older firms that finance their investments via retained earnings tend to have realized returns that are

\footnotetext{
${ }^{24}$ The corporate and ownership tax policies are not the direct cause behind the enhanced pecking order of financing since they are primarily supportive of the ownership policies that promote separation of control form ownership. The tax policies have at the margin disfavored direct ownership by households and benefited institutional ownership, and disfavored equity as a source of capital, in particular when the inflation rate is high, while favoring debt and retained earnings. Table 7 shows the effective marginal tax rates for different type of owners and sources of financing at points in time when taxes were revised. A negative marginal tax rate indicates that the rate of return is greater than before: a marginal tax rate of $-83 \%$ for a debt financed investment by a tax-exempt institution transforms to $10 \%$ real return before tax to $18.3 \%$ return after tax. The taxes on debt, equity and retained earnings were rather differentiated before the big tax reform in 1991 but have become more harmonized since then. Note that the most negative tax effects on equity ownership by households occurred before 1985 when the equity markets were dormant in Sweden.
} 
significantly below their cost of capital; investments financed via debt or equity do not seem to systematically underperform, see Holmén and Högfeldt (2004b). The free cash flow problem thus seems to be particularly serious for firms that have a well-defined owner in control and rely on retained earnings; they also tend to have higher investment-cash flow sensitivity. Inefficient investments due to (free) access to retained earnings may be the very reason why firms with strong separation of control and ownership are traded at a discount.

Since the labor market laws in recent decades have promoted tenure with an employer, the combined effect of investment and labor market policies is therefore a significant lock-in of both labor and capital within the existing, large firms and their controlling owners. The biased investment criterion and the lock-in effects endogenously create a stronger path dependency as the firms' future developments (size, investments and growth) are more directly tied to past performance. The long-run effects on the firm structure will be a survival and growth bias: an overrepresentation of very large and old firms in mature industries and an underrepresentation of new and fast growing firms in new industries. Broadly consistent with this conjecture, Sweden has one of the most skewed distributions with an extreme dominance of very large and very old multinational firms still controlled by Investor and Industrivärden, and very limited addition of new fast-growing firms. Fig 5 shows for example that 31 of the 50 largest firms in 2000 were founded before 1914. No firm founded after 1970 has been added to the list. Moreover, measured by number of the Fortune 500 firms in 1991, Sweden ranked as \#6 with 15 firms on the list and with the highest number of firms per GDP unit (one billion US (PPP adjusted)): 0.104 (see Jagrén (1993)). The size distribution of Swedish firms (small, medium and large) is $84.1 \%, 12.1 \%$ and $3.7 \%$, respectively, compared to an international average size distribution of $87.5 \%, 10.2 \%$ and $2.2 \%$, respectively, which shows the bias towards larger firms (see Henrekson and Jakobsson (2001)). 
He, Morck and Yeung (2003) find that greater instability in the ranking over time of a country's largest firms is associated with faster economic growth. ${ }^{25}$ Economic growth is thus more likely to be caused by the rise of new large firms than by the prosperity of established large firms. Sweden has one of the most stable rankings over time but really stands out in their analysis as the only country where the continuity of control over time actually increases. ${ }^{26}$ That lock-in of family control for generations may have negative effects is a well-known phenomenon. For example, Holmén and Högfeldt (2004b) report a robust 14\% discount for large listed firms that are heir controlled. The conjecture that incumbency tends to breed complacency and stagnation, in particular when investments are financed via retained earnings, is consistent with Morck's at al's (2000) finding in a cross-country analysis that countries with a larger fraction of heir controlled firms tend to have a significantly lower overall growth rate. The dominance of the same firms among the very largest for decades as well as the extreme continuity of control in Sweden is thus consistent with a lower overall growth rate in the economy.

The strong path dependency is particularly conspicuous for the very important closed-end investment funds that control the largest listed firms since their shares trade at a significant discount (on average $25-30 \%$ ) relative their portfolio, which in effect makes it economically impossible for them to raise new equity capital via SEOs. The funds thus prefer that their portfolio firms primarily finance their investments by retained earnings and loans since these sources are relatively cheap although the firms are traded at a 6-8\% discount because being controlled via a pyramid; see Holmén and Högfeldt (2004b). Since intercorporate dividends are not taxed if they just pass through the pyramid holding company (the closed-end investment fund) on their way from the portfolio firms to the ultimate shareholders, the controlling owners are even more inclined to retain earnings in the portfolio firms. Since realized capital gains are not taxed if reinvested, the pyramid holding

\footnotetext{
${ }^{25}$ The faster growth is primarily due to faster growth in total factor productivity in industrialized countries, and faster capital accumulation in developing countries; see He et al (2003).

${ }^{26}$ They observe a very interesting fact: Note that control continuity is always less than corporate stability, except in the case of Sweden. This is because the Wallenberg family took control prior to 1996 of two new top ten firms that arose between 1975 and 1996. These two new top ten firms thus have a continuity of control. This situation arises in no other country; see He et al (2003).
} 
company avoid paying dividends themselves. The combined effect of the preferential tax treatment and the pyramid control structure is therefore that the portfolio firms systematically pay out less dividends and tend to overinvest, which the significantly higher investment-cash flow sensitivity and the significantly lower realized return on investments financed via retained earnings for pyramid firms shows (Holmén and Högfeldt (2004b)). Moreover, since the two leading banks are both controlling owners of the most important pyramids and the major providers of loans to the portfolio firms, they tend to behave more like bondholders: accumulation of hidden reserves and choice of conservative investment strategies that focus on long-run survival and stable cash flows, not on risk taking and entrepreneurship.

The lock-in effect and the biased investment criterion have especially negative long-run effects since the portfolio firms are in old and often capital-intensive industries. In particular since these firms tend to invest heavily in $\mathrm{R} \& \mathrm{D}$, often along the narrow trajectory previously chosen by a specializing strategy (few and highly specialized areas with relatively large production volumes), and not in a diversifying direction in alternative technologies (see Erixon (1997)). The old established firms have their comparative advantage in the commercial implementation and marketing of large scale research projects, not in major breakthrough patents and innovations. While neither R\&D investments nor the number of resulting patents are necessarily small, the endogenous effect is that it perpetuates a development path that leads to an even smaller and narrower base of highly specialized firms that might not generate high growth and that may also be economically vulnerable due to shifts in technology. An interesting fact is that of 100 major innovations in the Swedish industry during the post-war period more than 80 occurred in large firms (see Granstrand and Alänge (1995)).

Through strong path dependency, the old established, large scale industrial structure is thus pushed to its limits by political and endogenous economic decisions that determine the investment strategies and how they are financed. After 100 years of unprecedented growth (among the 3 highest ever recorded for a 100 year period), Sweden ranked as one of the three wealthiest OECD 
countries in 1970. Due to lack of resiliency of the stale economic and political structures, recurrent and prolonged adjustment problems in the aftermath of the oil crises (6 devaluations), growth has been significantly lower during the last 30 years and Sweden now ranks behind neighboring countries. The relationships presented here between the characteristics of heavily entrenched corporate control and growth provide a more plausible and direct explanation of why the Swedish economy has shown signs of stagnation than the alternative that pinpoints the negative effects of higher taxes and of a larger public sector; see Lindbeck (1997). ${ }^{27}$

Maintained private control by increasing separation of votes from capital makes the capital base too small and increases agency costs and inefficiencies.

When the increased international competitive pressure in the $60 \mathrm{~s}$ and 70 s forced highly levered Swedish firms to invest more, particularly in $R \& D$, and needed to finance takeovers and mergers to exploit scale advantages, the volume of SEOs increased considerably for the first time since the 30s. Because of the strong preference for maintained control, the frequency of listed firms that use dualclass shares increased significantly; from $18 \%$ in 1950 to $32 \%$ in $1968 ; 54 \%$ in 1981 and peaked at around $80 \%$ in 1992 to settle at $63 \%$ in 1998 and below $60 \%$ after the IT-bubble busted (see Agnblad et al (2001), Holmén and Högfeldt (2004a) and Henreksson and Jakobsson (2003a and b)). ${ }^{28}$ The high frequency of dual-class shares to separate votes from capital is thus a fairly recent phenomenon and most prevalent among family controlled firms (see Agnblad et al (2001)). This development has received political support since firms with well-defined private owners in control are believed to be more efficient; families have a long-term commitment as the growth of private fortune is tied to the firm's development. In the 80 s and particularly after 1993 , when all restrictions on foreign ownership of shares were abolished, the political ambition (sometimes explicit but most often implicit) has been to promote maintained control in order to keep corporate headquarters,

\footnotetext{
${ }^{27}$ It is ironic that since 1997 when Lindbeck presented his dire and one-sided predictions about the future development of the Swedish economy, the macroeconomic performance and growth has at least equaled if not surpassed that of comparable EU countries.

${ }^{28}$ In 1950 only $18 \%$ of 100 largest firms used dual-class shares; $29 \%$ in 1963 ; and $42 \%$ in 1978 .
} 
specifically R\&D, marketing and strategic functions, in Sweden. This illustrates the political foundation and sensitivity of corporate control in Sweden. The political support for extensive use of dual-class shares and pyramiding is traded-off against the indirect (direct) promise that the largest firms continue to invest in Sweden and do not migrate. Dual-class shares and pyramiding are in fact the very cornerstones of the Social Democratic model of corporate ownership. ${ }^{30}$

Despite much larger foreign ownership (35\% of outstanding shares), almost exclusively via B-shares, and much more institutional ownership, the old families and closed-end investment funds have been able to maintain a somewhat diluted control by increasing use of dual-class shares combined with reinforced protection of incumbent owners via mandatory bid rules and more stringent takeover rules that de facto increase entrenchment. However, in very large international mergers motivated by scale effects and very large R\&D costs, the separation of votes and capital has not been enough to maintain control; Investor lost control of Stora (pulp and paper) and Astra (pharmaceutical) in mergers with Enso and Zeneca, and earlier of ASEA in a merger with Brown Boveri- ABB. Despite some dilution of control and much larger capital needs, it is remarkable that established families and closed-end funds are still very often in control. But the increased separation between votes and capital undercuts the very justification for capitalistic firms as a small capital contribution generates control over all other investors' capital, in particular as the vote lever is often justified on historical grounds. The system therefore also becomes more politically vulnerable as for example the recent EU-initiative to abolish dual-class shares shows.

The strong separation between votes and capital generates two principal types of costs that are primarily borne by the non-controlling shareholders. Either costs because of extraction of

\footnotetext{
${ }^{29}$ A public inquiry about voting rights states explicitly that dual-class shares could be useful to ascertain that Swedish firms remain controlled by Swedish interests (see SOU 1986:23). More recently, the fight against EU proposals to in effect abolish the use of dual-class shares has been spearheaded by the Wallenberg family via Investor whose shareholders paid for the campaign. The Social Democratic government announced that it would do everything within its power to back the Wallenbergs and fight the proposal. The right to use dual-class shares is declared to be a national interest.

${ }^{30}$ A public inquiry about voting rights stated explicitly that dual-class shares could be useful to ascertain that Swedish firms remain controlled by Swedish interests (see SOU 1986:23). More recently, the fight against EU proposals to in effect abolish the use of dual-class shares has been spearheaded by the Wallenberg family via Investor whose shareholders paid for the campaign. The Social Democratic government announced that it would do everything within its power to back the Wallenbergs and fight the proposal. The right to use dual-class shares is declared to be a national interest. If dual-class shares would be prohibited in the future, it is very likely that the Swedish model as we know it would disintegrate.
} 
pecuniary benefits (self-dealing) by the controlling owners or agency costs due to bad (inefficient) decision making. Since the corporate law is designed to handle the problems with self-dealing and legal as well as tax enforcement are stringent, agency costs are the most likely reason behind the discounts on firms with levered control structure; see Roe (2002a). For example, Holmén and Högfeldt (2004b) did not find any indication of tunneling (corporate stealing) in Swedish pyramids that have the most levered control structures. Moreover, since the increased use of dual-class shares to maintain control implies that the capital base for control becomes smaller, i.e. the leverage effect in votes increases, which tend to increase the agency costs as the difference between the power to make pivotal decisions and the private value at risk for controlling owners increases. This effect is amplified by the lock-in of control for generations by the same family. In Schumpeterian spirit, such dynamic agency costs can be substantial as the entrepreneurial genes and drive do not replicate easily; see Holmén and Högfeldt (2004a)). The discounts on family controlled firms thus most likely gauge such agency costs due to misallocation of control rights to heirs that make inefficient decisions, e.g. due to significant lower returns on investments financed via retained earnings; see Cronqvist and Nilsson (2003) and Villalonga and Amit (2004).

The importance of agency costs due to a significant lock-in of control over the largest firms for a very long time can best be illustrated by the very large discounts on closed-end investment funds (CEIF -- the pyramid holding companies); see Holmén and Högfeldt (2004b). The vote lever is particularly large since Swedish funds combine separation via pyramiding and dual-class shares, which generates a multiplicative effect. Since Investor has a voting differential of 1:10 while Ericsson was the only listed firm on the SSE (until 2004) that had a 1:1000 differential, the multiplier for the ownership of the Wallenberg family in Ericsson is 125 - their own contribution is only about $0.8 \%$ of Ericsson's capital while they control $+80 \%$ of the votes jointly with Industrivärden. After the reform, the two major owners control around $40 \%$ of the votes.

Fig 6 shows that the discount on Investor's share price relative the fund's net asset value from 1930 to 2002 has been substantial (averages about 30\%), in particular in the 70s when its was 
around $40 \%$. After being cut to almost $20 \%$ in the early 90 s, the discount is now again back at around $35 \%$. In addition, the portfolio firms have a $6 \%$ discount due to being under pyramidal control. Analyzing all CEIFs, Holmén and Högfeldt (2004b) find that the discount increases linearly with the controlling owner's degree of separation between votes and capital in the fund and with the number of years the present owner has been in control. The discount is thus significantly higher for founder-controlled pyramids, i.e. it gauges the cost of pyramidal power as it becomes more levered and more entrenched. The results are consistent with controlling owners becoming more dependent on the multiplicative separation between votes and capital over time. Pyramidal separation is thus not a static phenomenon since the use of dual class shares is intensified in order to maintain control.

The discounts are primarily explained by dynamic agency costs (inefficient decisions) associated with the heavily entrenched power. For example, Holmén and Högfeldt (2004b) report that the CEIFs' active portfolio management generates a return that is significantly below their cost of capital when capital gains are re-invested instead of being distributed. In particular, a passive portfolio management by just holding the portfolio generates a significantly higher return than actively managing it according to the pivotal owners' specific interests. This in effect limits their investments to projects where they have a controlling interest, which in turn often implies that bad projects are supported too long; the soft return requirements on retained earnings reinforce these effects. The lower returns translate to into a loss (outflow) in the shareholders' return stream from the investment.

A standard neoclassical model predicts that the discount is simply the ratio of the capitalized value of the outflow, which does not go to the CEIF's shareholders, to the total value of all outflows from the CEIF, i.e. including the dividends going to the shareholders, see Ross (2002). Holmén and Högfeldt (2004b) empirical estimate of this theoretical ratio- fraction of all outflows that do not go to the shareholders - gives a discount of 25.3 percent compared to the actual average discount of 26 percent. The size of the agency costs is on average 0.7 percent of the CEIFs portfolio value, and increase with separation between votes and capital in the CEIF. Since the size of the 
discount is directly linked to the control structure and power of the controlling owners, the model in effect explains the large discounts in Sweden, and provides a solution to the closed-end fund puzzle.

Shareholders are in principle privately compensated for the costs of pyramidal ownership through the discounts, but pyramiding has also a negative impact on the efficiency of the capital allocation in the economy that is probably significantly larger. Almeida and Wolfenzon (2004a) has developed an interesting model of the equilibrium allocation of capital when the comparative advantage of capital markets in reallocating capital, especially in time of change, is not at work. They show that the overall efficiency may decrease in the presence of conglomerates, even when capital is allocated efficiently within the conglomerate. The reason is that local efficiency within a subset of firms does not correspond to global efficiency as capital is not efficiently allocated between all firms.

Unlike with conglomerates, the problem with pyramidal control is not inefficient internal capital markets since no direct capital transfers between pyramid firms are possible. The major problem is instead that too much capital is locked into the separate firms within the pyramid and not redistributed since the highly levered control structure causes an enhanced (political) pecking order since external capital is significantly more expensive than internal capital. ${ }^{31}$ Firms controlled by pyramids are thus likely to be overcapitalized by relatively cheap internal capital, which may lead to overinvestment, particularly in fixed assets (PPE) and R\&D, and lower returns than required by the market (cost of capital). Pyramids may thus have a strategic negative impact on corporate financing and investments because of their limited dependence on the primary equity markets and because they retain too much earnings in firms that are primarily in mature industries. ${ }^{32}$ Since not enough of the old capital (for control reasons) is reallocated via the external equity markets to e.g. fledgling firms in new, growing industries, pyramiding hampers both the development of financial

\footnotetext{
${ }^{31}$ Unlike the discount on conglomerates, the large discount on pyramid holding companies cannot be explained by inefficiencies in the portfolio firms since this is already reflected in the value of the holding firm's portfolio.

${ }^{32}$ The reason why pyramids exist is profoundly political; see Morck (2003) and Holmén and Högfeldt (2004b). Their structure is however not primarily explained by the controlling owners desire to exert power as such but to get control over a large and relatively cheap source of financing; control over very large cash flows via a small but strategic investment; see Holmén and Högfeldt (2004b).
} 
markets and the overall growth. These negative effects may be particular significant in Sweden since the pyramids have had strategic control over the largest and oldest listed firms for decades.

Preference for maintained control implies limited use of equity financing and that too few firms grow to became large

Egalitarianism may be conducive to dynamic changes as evident from the labor market policies that were designed to promote mobility and structural changes in socially more acceptable forms. But when the objective to promote or contain a less dispersed distribution of wealth disfavors equity financing in general, and, in particular, limits the possibilities for newly founded firms to grow fast using equity financing, there exists a conflict between egalitarianism and dynamic growth. The opportunities for entrepreneurs to build private fortunes by developing new firms have been limited because of tax reasons but also since the strong preference for maintained control in effect limits the volume of equity financing, and in particular the use of public offers. This preference might be primarily a cultural trait but is more likely to be an equilibrium outcome that is endogenously generated by the corporate ownership model reinforced by the design of the tax system, i.e. by the enhanced political pecking order of financing. The preference for control implies limited use of equity financing because it disperses ownership and slow growth rate since the capital infusions are relatively small — too few firms grow fast to become large. The political disfavoring of equity financing and favoring of retained earnings and loans have reinforced this effect. Hence, there are effects both on the demand and on the supply side that limit equity financing in equilibrium.

In line with the pecking order theory of SEOs, the largest offers for IPO firms are rights issues that dilute control the least (see Holmén and Högfeldt (2004a)). However, they are still too small to generate a high growth rate for newly listed firms controlled by the founding entrepreneur. In general, family controlled IPO firms are undercapitalized because of the preference for control. The strong preference for maintained control and use of retained earnings as the preferred method of financing also limits the growth rate of SMEs. For a sample of 1248 firms with 5-49 employees, Wiklund, Davidsson and Delmar (2002) report that the entrepreneur prioritizes growth only if 
he/she does not lose control and independence of other stakeholders while the well-being of their employees is not compromised. They strongly prefer financing via retained earnings even if they are aware that the firm will follow a trajectory with lower growth than with equity financing. $44 \%$ say that they would rather sell the whole firm than share control even if it would improve performance and growth. Moreover, firms where the founder's family owns a smaller fraction and/or have more ownership categories are more likely to grow faster.

Since the formation of new firms has been relatively low and decreasing until the mid-90s, the addition of new firms that grow fast has been limited. Together with the limited use of equity financing to support fast-growing firms this implies a skewed size and age distribution of firms with negative effects on future growth. The incapacity to use equity financing to promote growth of new firms in advancing industries may be the real Achilles' heal of the Swedish model.

\section{A summary: An integrated answer}

An integrated, general answer to the three questions about how corporate ownership developed in Sweden, why the Social Democrats accepted a very concentrated private ownership and control over listed firms and why ownership did not separate widely in Sweden is structured as follows.

The Swedish corporate ownership model is built on a basic understanding between the Social Democrats (labor) and capital: political support and legitimacy of heavy entrenched private ownership is traded-off against the implicit guarantee that the largest listed firms do not migrate and that they continue to invest. The strong separation of ownership and control causes an enhanced (political) pecking order of financing that is endogenously supported by the interests of the two incumbencies.

The incumbent capital's strong preference for maintained control of listed firms implies a priority for financing via retained earnings and loans, and only limited use of equity financing when needed since this would disperse ownership and eventually control, in particular if public offers are

\footnotetext{
${ }^{33}$ Using somewhat fragmentary data, Braunerhjelm and Carlsson — Entrepreneurship, small firms and industrial growth in Ekonomisk Debatt 1995 - report that annual entry rates of new manufacturing firms with more than one employee have been very low and fell from about $4 \%$ to $2 \%$ rates from 1920 to 1950 , to $1.5 \%$ in the 70 s and below that in the 80 s.
} 
used. For different reasons, the political ordering of financing alternatives by the Social Democrats was the same. The ideological focus on the largest listed firms and their investments combined with skepticism towards equity markets in general, and the primary markets in particular for egalitarian reasons, implied a strong preference for retained earnings and loans. The existing strongly relationbased banking system supported this ordering and so did the explicit political support for use of devices to separate votes from capital via pyramids and specifically for dual-class shares when the firms needed more equity financing. As the incumbent capital became more institutionalized while creation of large private fortunes in new firms via significant equity financing is limited and does not threaten to disperse the distribution of wealth too much, the order was also politically acceptable. It is worth emphasizing that this line of arguments pinpoints the political sensitivity of the equity markets' primary function and not their secondary function to provide liquidity, which is more standard.

The resulting equilibrium perpetuates and reinforces the initially concentrated ownership of the largest listed firms since ownership does not have to disperse because of significant need for equity financing — ownership becomes more entrenched as separation of votes and capital increases over time. Since historical profits determine future investments and not expected future profits, the equilibrium entails a strong path dependency: dominance of very large and old firms in mature

industries that tend to overinvest while there are relative few new and fast-growing firms in advancing lines of business. Since the labor market policies promote tenure with the existing employer, both labor and corporate control are locked-in with the existing firms. The old industrial structure is thus taken to its limits by the strong path dependency of corporate control, investments, labor and political power. The almost innate entrenchment of both the political and corporate powers breeds economic stagnation as well as lack of social dynamics.

\section{Why did corporate ownership in Sweden follow this particular historical path?}


The purpose of this section is to very briefly outline some general factors and correlations between them that have been particularly important determinants of the development of corporate ownership in Sweden. My conjectures are of course subjective, very speculative and incomplete as I focus on the overall picture from a specific financial perspective but the institutional and political stability makes it perhaps both easier and more interesting at the same time to outline a hypothetical answer. I conjecture that the following causal chain between some of these categories (factors) have been particularly important. ${ }^{34}$

When Sweden started its modern economic development about 150 years ago, the country was relatively well endowed with natural resources (e.g. minerals, forests and water power), mainly located in the northern part of the country, but large capital investments were needed to fully exploit the endowments. The lack of domestic capital and of a sufficiently large group of wealthy people, left two alternative ways to raise the necessary capital: collection of many peoples small savings via a domestic system of saving and deposit banks and borrowing via issuing of bond loans abroad (perhaps also migration of wealthy persons and entrepreneurs). The very large emigration wave to North America increased the political pressure to modernize the very poor country. The reasons behind the country's poverty and what to do about it were the major political issues. How to organize an efficient banking system, and how to reform it as the financing demands changed were hotly debated questions for many decades. Political reforms paved the way for a banking system of Scottish type and very large bond loans to finance infra-structural investments were sold to French, German but also to English investors.

Economic geography is very important since the country is located on the northern rim of Europe but has a very long costal line. Since the Hanseatic times Sweden has been connected with

\footnotetext{
${ }^{34}$ In general, I think (without explicitly motivating it here) that an empirically relevant theory of the historical development of corporate ownership and its importance for financial development and growth should consider (at least) seven broad categories: 1. Endowments (natural resources, geography and population) and production technologies; 2. Level and distribution of wealth (poverty); 3. Openness of society (transparency and competitiveness); 4. Legal system and enforcement; 5. Political system (ideology, electoral system, tax system); 6. Structure of financial system (relation based - arm's length); and 7. Major "random" events (e.g. wars and The Great Reversal). The ordering is convenient and does not reflect the categories' relative importance. The two literatures on finance and growth (see e.g. Beck et al (2000) and Carlin and Mayer (2003)) and on the political economy of corporate finance (see e.g. Pagano and Volpin (2001)) have identified specific factors for crucial for financial development but it would take me too far astray to discuss it now.
} 
Continental Europe and partly integrated via the Baltic Sea but also with the British Isles, Amsterdam and Hamburg via the North Sea, and later also part of a North Atlantic economy after the great emigration. The export of raw materials had gone on for centuries, which developed an awareness of being part of an international market economy and fostered market discipline. Financial transfers had also been crucial as for example Sweden's wars were financed out of Hamburg and Amsterdam. Trade credits and short term borrowing were later used efficiently as they de facto became long term capital. As people migrated to develop their know-how and skills abroad, cultural values, ideas, technological knowledge and market knowledge were transferred to Sweden when they returned. Being a small country, the national culture is the cumulative result of influences from several different cultures. Despite an under-developed civic society, the country was thus relatively open; the tensions within the elites were between the international modernity and the parochial Swedish traditionalism. The long-time international integration into a larger market economy provided the necessary basis for the late but fast and successful industrialization of Sweden. The early formation of several new firms based on break-trough innovations that are still important today would probably not have taken place if not the engineers and entrepreneurs had traveled and been internationally connected and the basic skills and training already in place via the long experience of export-oriented production.

When the capital demands for large scale industrial investments increased about 100 years ago, the financial system could in principle have developed into a market-based system of equity and bond financing but the political power of the commercial banks, combined with support from the Social Democrats, instead extended the intermediated system into equity financing by the banking law of 1911 that permitted banks to operate as investment banks and directly own equity. The fledgling stock market was too speculative to become an alternative source of outside financing. The relatively large equity issues in the 1910 s and 1920 s were primarily financed the levered Issuing Companies controlled by banks at very short arm's length, and not via public offers. 
Without the bank law of 1911 it is likely that corporate ownership would have developed quite differently; the law was the pivotal reason banks ended up holding large equity portfolios of very financially distressed firms in the early 1930s. When the new bank law of 1934 prohibited banks to directly own equity, they were allowed to transfer them to closed-end investment funds instead of forcing the banks to sooner or later sell these assets back to the market when prices rebounded. The leading banks could thus continue to exert control over the largest listed firms, even if it formerly was at arm's length. Unlike in the US, the banks were not the problem in Sweden but the solution to the problem of how to create financial and social stability, and to restructure the large industrials. The main banks were financially healthy enough, experienced as investment bankers and had developed the political contacts.

Like in the US, the policies after the deep financial crises shaped the future developments through a strong political and regulatory path dependency. This large random event had however an even larger impact in Sweden as the crises was the start of both the political hegemony of the Social Democrats and of the political model of entrenched corporate ownership with the banks as the pivotal nodes for corporate control; financial intermediation was de facto extended into highly levered corporate control via pyramiding. A short term and acute solution to the poorly functioning financial markets was extended for decades through the political hegemony and the basic understanding between labor and capital. Corporate ownership is thus very political indeed.

In the early 1980s when deregulation of financial markets started and stock markets were re-activated, the increased use of dual-class shares was backed by strong political support. The Bshares provided the necessary liquidity and dispersion of ownership (capital) while the control rested firmly with the traditional private owners that increased their separation between control and ownership when market values and capital demands increased. Because of the control structure, the primary market for equity did not develop fully and the system in effect continued to be very dependent on intermediated financing and retained earnings (a reactive financing mode) even 
though the tensions between ownership and control are growing and attracting attention from politicians who would reform the system.

I thus think it is possible to identify a simple causal chain that explains why the Swedish financial system has not developed into a fully market-based financial system with very active primary markets and dispersed corporate ownership. Given the poverty and lack of wealthy individuals, and the use relatively capital-intensive technologies and large-scale production, a system of intermediated financing was politically chosen to collect and allocate the capital. The defining moments for the developments of the financial system are 1911, 1934-37 and 1984 when the intermediated system was extended into equity financing (banks were allowed to directly own shares), when banks became the pivotal controlling owners of the largest firms and when the equity markets were re-activated (The Great Reversal was reversed) but the heavily entrenched control structure was maintained and reinforced by increased use of dual-class shares, respectively. At these three turning points the development of the financial system as well as of corporate ownership and control could have followed other paths than they did if the political decisions had been different. Because of the strong path dependency in an intermediated financial system when it is supported by political powers united by common interests, a genuinely market-based financial system has not developed in Sweden.

However, it is almost impossible to underestimate the persistent effects even today of the major random event: the crises in the early in the early 1930s that was the catalyst of both the political hegemony of the Social Democrats and the very strong and growing entrenchment of private corporate control. Even if these two phenomena are not always analyzed as causally connected, it is almost inevitable not to regard them as Siamese twins in an analysis of the development of corporate ownership in Sweden as I have done in this paper.

\section{Conclusions}


100 years ago modernity in Sweden was spearheaded by the rapidly advancing industrial sector and carried by its two new social groups - capital and labor-- that reshaped the economic, political and social arenas. A relatively small group of leading industrialists and bankers, most often recruited outside the establishment, represented the commercial interests, had a pronounced Anglo-Saxon orientation and were politically active with a stress on rational reforms to promote changes. The well-organized labor movement (SAP and LO) transformed their more radical, original revolutionary objectives into a reformist agenda pursued by democratic, parliamentary means, and viewed itself as the carrier of future social and economic changes of historical proportions. Despite significant ideological influence from Germany, the leadership was primarily stimulated by ideas from the British labor movement that could be implemented politically. Even though labor and capital had adversarial interests, they shared a common sense of being harbingers of modernity. Together with the Liberal Party the Social Democrats successfully fought for general and equal suffrage (implemented in 1921) against The old Right that was organized around the (autocratic) king and supported by the nobility, the church, the military, the leading civil servants and the large farmers. The Right had by tradition looked towards Germany for guidance and emphasized social and cultural values embodied in strong Lutheranism, nationalism and traditionalism with support for the monarchy and social order, mixed with disdain for the commercial Anglo-Saxon countries and their (lack of) values.

Unlike in Germany where the Old Right was fuelled by revenge after WW1 and the transition to modernity was violent and resulted in the direst consequences for Europe, the transition in Sweden was peaceful despite weak governments and economic crises of the 20 s and early 30 s. In 1932 the Social Democratic vision of The Good Home (Folkhemmet) was not only the political answer to the turbulent economic and political times with its focus on full employment policies but represented also the democratic modernity with strong emphasis on egalitarian values, and encompassing policies based on social and economic rationality with a (benevolent) paternalistic flavor mixed with some mild nationalism. To implement the vision of the good society, the 
economic policies promoted growth and full employment, particularly in the post-war period until the 70s, and development of a large public sector. Embodied in the elaborate welfare state and in the political hegemony of the Social Democrats, it is the most successful and long-lived political vision ever in a democracy.

But when the industrial society reached its peak in the mid 70 s, and 40 years of strong growth turned into almost 30 years of relative stagnation and recurrent economic, financial and budget deficit crises, and significant loss of economic welfare, the weaknesses became all too apparent: the lack of resilience of a too small base of very large, old and highly specialized firms in stagnating industries and lack of new growing firms in advancing industries. On ideological grounds the Social Democrats focused on the largest listed firms, in particular their investments and R\&D spending, and promoted policies that supported financing via retained earnings and borrowing from a strongly relation-based banking system but disfavored equity markets as supplier of capital for egalitarian reasons. Their political support for use of dual-class shares and pyramiding in effect aligned the interests of the incumbent political power with incumbent capital (in particular the leading banks) as corporate control is maintained and actually reinforced. Capital is locked in with the incumbent firms since the separation of control from ownership drives a wedge between the costs of internal and external capital that causes an enhanced (political) pecking order of corporate financing. Investments are thus primarily determined by historical profits, not by expected future profits.

Listed firms have indeed not been dependent on the primary equity markets while formation of private fortunes tied to new, fast-growing firms fuelled by equity market financing has been very limited. This explains both why ownership did not disperse and why addition of new firms has been so poor. Since labor market rules are designed to protect incumbent workers, both labor and control over capital are therefore locked into the existing corporate structure while the Social Democrats have locked in the political sector. The real problem with the Swedish model of 
corporate ownership is thus the lack of economic and social dynamics - modernity has become stale and embedded.

The strong historical and political path dependency is apparent in the fact that the two socio-economic groups that spearheaded modernity 100 years ago- leading capitalists and organized labor - are still the heavily entrenched incumbencies even if the importance of the industrial society has been declining for decades. ${ }^{35}$ The real irony is that corporate control, although diluted in recent years by increased institutional ownership, is still in the hands of very few, wellestablished families and banks, not despite but because of Social Democratic policies.

The Social Democrats in effect became the guarantor of heavily entrenched private corporate ownership rather than the terminator of capitalism since the political and corporate incumbencies have been united by strong common interests. Incumbent owners need the political support to legitimize that their corporate power rests on extensive use of dual-class shares and pyramiding. While the Social Democrats only get the necessary resources and indirect support for their social and economic policies from the private sector if the largest firms remain under Swedish control so that capital does not migrate. By not encouraging outsiders to create new firms and fortunes, and by not fully activating the primary equity markets, the heavy politicized system has redistributed incomes but not property rights and wealth. The result is an ageing economy with an unusually large proportion of very old and very large firms with well-defined owners in control.

${ }^{35}$ Path dependency is here used in a wider more general sense than in e.g. Bebchuk and Roe (1999). 


\section{References}

Agnblad, Jonas, Erik Berglöf, Peter Högfeldt and Helena Svancar, 2001, Ownership and control in Sweden: Strong owners, weak minorities, and social control, in Fabrizio Barca and Marco Becht (eds) The Control of Corporate Europe, Oxford University Press

Allen, Franklin, and Douglas Gale, 1999, Diversity of opinion and financing of new technologies, Journal of Financial Intermediation 8, 68-89.

Almeida, Heitor, and Daniel Wolfenzon, 2004a, Equilibrium costs of efficient internal capital markets, Working paper, New York University.

Almeida, Heitor, and Daniel Wolfenzon, 2004b, A theory of pyramidal ownership and family business groups, Working paper, New York University.

Althaimer, Hans, 1988, Börsen och företagens nyemissioner (New equity issues on The Stockhom Stock Exchange 1902-1986) in Ingemund Hägg (ed) Stockholms Fondbörs. Riskkapitalmarknad i omvandling. SNS Förlag, Stockholm.

Bebchuk, Lucian A., and Mark, J., Roe, 1999, A theory of path dependency in corporate governance and ownership, Stanford Law Review 52, 127-170.

Bebchuk, Lucian A., 1999, A rent-protection theory of corporate ownership and control, NBER Working paper \#7203.

Bebchuk, Lucian A., Reinier Kraakman, and George Triantis, 1999, Stock pyramids, cross-ownership, and dual class equity: The creation and agency costs of separating control from cash flow rights, NBER Working paper \#6951.

Becht, Marco, Patrick Bolton, and Ailsa Röell, 2002, Corporate governance and control, Working paper, ECGI, Brussels.

Beck, Thorsten, Ross Levine, and N. Loayza, 2000, Finance and the sources of growth, Journal of Financial Economics 58, 261-300.

Bertrand, Marianne., Paras Mehta, and Sendhil Mullanaithan, 2002, Ferreting out tunnelling: An application to Indian business groups, Quarterly Journal of Economics, 121-148.

Bonbright, J.C., and Gardiner. C. Means, 1932, The holding company: Its public significance and its regulation, New York, McGraw-Hill Book Co.

Burkart, Mike, Fausto Panunzi, and Andrei Shleifer, 2003, Family firms, Journal of Finance. 58, 2167-2202

Carlin, Wendy, and Colin Mayer, 2003, Finance, investment, and growth, Journal of Financial Economics 69, 191-226.

Cronqvist, Henrik, and Mattias Nilsson, 2003, Agency Costs of Controlling Minority Shareholders, Journal of Financial and Quantitative Analysis, 38, 695-719.

Dahmén, Erik, 1950, Svensk industriell företagarverksamhet, Kausalanalys av den industriella utvecklingen 1919-1939 (Entrepeneurship in Sweden: A causal analysis of industrial dynamics in Sweden 1939-1939), IUI, Stockholm.

Dyck, Alexander, and Luigi Zingales, 2004, Private Benefits of Control: An International Comparison, Journal of Finance 59, 537-600. 
Erixon, Lennart, 1997, The golden age of the Swedish Model: The coherence between capital accumulation and economic policy in Sweden in the early postwar period, Report 97:9, Institute for Social Research, Oslo.

Fritz, Sven, 1990, Affärsbankernas aktieförvärvsrätt under 1900-talets första decennier, (The right of commercial banks to acquire shares during the first decades of the $20^{\text {th }}$ century) Acta Universitatis Stockholmiensis; Stockholm Studies in Economic History 14, Almqvist \& Wicksell International, Stockholm.

Galbraith, John Kenneth, 1967, The new industrial state, Houghton Mifflin, Boston.

Glete, Jan, (1994), Nätverk i näringslivet: Ägande och industriell omvandling $\square$ d et mogna industri-samhället 1920-1990 (Corporate Networks: Ownership and industrial restructuring in the mature industrial society), SNS Förlag, Stockholm

Granstrand, Ove, and Sverker Alänge, 1995, The evolution of corporate entrepreneurship in Swedish industry: Was Schumpeter wrong, Journal of Evolutionary Economics 5, 133-156.

Gårdlund, Torsten, 1947, Svensk industrifinansiering under genombrottsskedet 1830-1913 (Financing of Swedish firms during the formative years 1830-1913), Svenska Bankföreningen, Stockholm.

He, Kathy S., Randall Morck, and Bernard Yeung, 2003, Corporate stability and economic growth, Working paper, School of Business, University of Alberta.

Hedborg, Anna, and Rudolf Meidner, 1984, Folkhemsmodellen (The Swedish Model), Rabén \& Sjögren, Stockholm.

Helleiner, E, 1994, From Bretton Woods to global finance: A world turned upside down, in R. Stubbs, and G. Underhill (eds) Political economy and the changing global order, Toronto.

Henreksson, Magnus, and Ulf Jakobsson, 2001, Where Schumpeter was nearly right - the Swedish model and Capitalism, Socialism and Democracy, Journal of Evolutionary Economics 11, 331-358.

Henreksson, Magnus, and Ulf Jakobsson, 2003a, The transformation of ownership policy and structure in Sweden: Convergence towards the Anglo-Saxon model?, forthcoming in New Political Economy.

Henreksson, Magnus, and Ulf Jakobsson, 2003b, The Swedish model of corporate control in transition, SSE/EFI Working Paper No. 521, Stockholm School of Economics

Hermansson, Carl-Henrik, 1965, Monopol och storfinanns-de 15 familjerna. (Monopoly and leading capitalists: The fifteen families), Rabén och Sjögren, Stockholm

Holmén, Martin, and Peter, Högfeldt, 2004a, A law and finance analysis of Initial Public Offerings, Journal of Financial Intermediation. 13, 324-358.

Holmén, Martin, and Peter, Högfeldt, 2004b, Pyramidal discounts: Tunneling or agency costs?, Working paper, ECGI and Stockholm School of Economics.

Högfeldt, Peter, and Andris Oborenko, 2004, Does market timing or past profitability determine the capital structure? Working paper, Stockholm School of Economics.

Jagrén, Lars, 1993, De dominerande storföretagen (The domineering transnational firms) in Den långa vägen, The Research Institute of Industrial Economics, IUI, Stockholm.

Jörberg, Lennart, 1988, Svenska företagare under industrialismens genombrott 1870-1885 (Swedish entrepreneurs during the industrial breakthrough 1870-1885), Lund Studies in Economics and Management 2, Lund University Press, Lund 
Korpi, Walter, 1978, The Working Class in Welfare Capitalism - Work, Union and Politics in Sweden, Routledge \& Kegan Paul, London.

La Porta, Rafael, Florencio Lopez-de-Silanes, and Andrei Shleifer, 1999, Corporate ownership around the world, Journal of Finance 54, 471-517.

La Porta, Rafael, Florencio Lopez-de-Silanes, Andrei Shleifer, and Robert Vishny, 2000, Investor protection and corporate governance, Journal of Financial Economics 59, 3-27.

Larsson, Mats, 2002, Storföretagande och industrikoncentration (Mergers and acquistions among large listed firms in Sweden 1913-38), in Maths Isacson and Mats Morell (eds) Industrialismens tid: Ekonomiskhistoriska perspektiv på svensk industriell omvandling under 200 år, SNS Förlag, Stokcholm.

Lindbeck, Assar, (1997), The Swedish experiment, Journal of Economic Literature, XXXV, 1273-1319.

Lindgren, Gunnar, 1953, Shareholders and shareholder participation in the larger companies' meetings in Sweden, Weltwirtschaftliches Archiv 71, 281-298.

Lindgren, Håkan, 1994, Aktivt ägande: Investor under växlande konjunkturer (Active ownership: Investor in variegating business cycles since 1916), Institute for Research in Economic History, Stockholm School of Economics, Stockholm.

Lindgren, Håkan and Hans Sjögren, 2003, Banking systems as ideal types and as political economy: The Swedish case 1820-1914, in D.J. Forsyth and D. Verdier (eds) The Origins of National Financial Systems. Alexander Gerschenkron reconsidered, Routledge, London.

Maddison, A., (1982), Phases of capitalist development, Oxford University Press, Oxford.

Meidner, Rudolf, 1978, Employee investment funds: An approach to collective capital formation, George Allen \& Unwin, London.

Morck, Randall K., David A. Strangeland, and Bernard Yeung, 2000, Inherited wealth, corporate control, and economic growth: The Canadian disease, in Randall. K. Morck (ed), Concentrated Corporate Ownership. University of Chicago Press, Chicago.

Morck, Randall, 2003, Why some double taxation might make sense: The special case of inter-corporate dividends, Working paper 9651, NBER.

NUTEK and ALMI, 2001, Tre näringspolitiska utmaningar - Allianser för hållbar tillväxt, (Three challenges for the industrial policy - Alliances for sustainable growth) NUTEK Förlag, Stockholm.

Pagano, Marco and Paolo Volpin, 2004, The political economy of corporate governance, forthcoming in American Economic Review.

Pagano, Marco and Paolo Volpin, 2001, The political economy of finance, Oxford Review of Economic Policy $17,502-519$.

Persson, Torsten, and Guido Tabellini, 2003, Political institutions and policy outcomes: What are the stylized facts?, Working paper IIES, Stockholm University.

Peterson, Tom, 2001, Promoting entrepreneurship: Bank-connected investment development companies in Sweden 1962-1990 in Magnus Henreksson, Mats Larsson and Hans Sjögren (eds), Entrepreneurship in business and research: Essays in honour of Håkan Lindgren, Institute for Research in Economic History, Stockholm School of Economics, Stockholm.

Rajan, Raghuram G., and Luigi Zingales, 2003a, The great reversals: The politics of financial development in the $20^{\text {th }}$ century, Journal of Financial Economics 69, 5-50. 
Rajan, Raghuram G., and Luigi Zingales, 2003b, Saving Capitalism from the Capitalists: Unleashing the Power of Financial Markets to Create Wealth and Spread Opportunity, Crown Business.

Reiter, J., 2003, Changing the microfoundations of corporatism: The impact of financial globalization on Swedish corporate ownership, New Political Economy 8.

Roe, Mark J., 2002a, Political Determinants of Corporate Governance: Political Context, Corporate Impact, Clarendon Lectures in Management Studies. Oxford University Press.

Roe, Mark J., 2002b, Corporate law's limits, Journal of Legal Studies 31, 233-271

Ross, Stephen A., 2002, Neoclassical finance, alternative finance and the closed-end fund puzzle, European Financial Management 8, 129-137.

Rydén, Bengt, 191, Fusioner i svensk industri (Mergers in the Swedish industry), IUI, Stockholm

Sjögren, Hans, 1995, Long-term financial contracts in the bank-oriented financial system, Scandinavian Journal of Management 10,315-330.

SOU 1968:7 Koncentrationsutredningen I, Finansdepartementet, Stockholm.

SOU 1968:3, Kreditmarknadens struktur och funktionssätt, Koncentrationsutredningen II, Finansdepartementet, Stockholm.

SOU 1988:38, Ägande och inflytande $i$ svenskt näringsliv: Huvudbetänkande från ägarutredningen, Industridepartementet, Stockholm.

SIND 1980:5, Ägandet i det privata näringslivet, Statens Industriverk, Stockholm.

SNS Ownership Project, 1988, Special reports by Ragnar Boman, Anna-Karin Eliasson and Barbro Sköldebrand.

Sundqvist, Sven-Ivan, and Ann-Marie Sundin, 1985-2002, Owners and Power in Sweden's Listed Companies, Dagens Nyheter, Stockholm.

Södersten, Jan, 1984, Sweden, in King, M.A. and Fullerton, D. (eds.), The Taxation of Income from Capital. A Comparative Study of the United States, the United Kingdom, Sweden and West Germany. Chicago: University of Chicago Press.

Villalonga, Belen, and Raphael Amit, 2004, How do Family Ownership, Management, and Control Affect Firm Value?, Working paper, Harvard Business School.

Wigforss, Ernst, 1980, Ernst Wigforss skrifter i urval I-IX, (A collection of Ernst Wigforss writings), Tidens Förlag, Stockholm.

Wiklund, Johan, Per Davidsson, and Fredric Delmar, 2002, What do they think and feel about growth? An expectancy-value approach to small business managers' attitudes toward growth. Entrepreneurship Theory and Practice.

Öberg, Ann, 2003, Essays on capital income taxation in the corporate and housing sectors, Economic Studies 72 (Doctoral thesis), Department of Economics, Uppsala University.

Östlind, Anders, 1944, Svensk samhällsekonomi 1914-1922: med särskild hänsyn till industrin (The Swedish economy 1914-1922, in particular the industrial sector), Stockholm. 
Table 1: Ownership and controlling owners in the 25 largest industrial firms in Sweden in 1925. Type of controlling owners: F (Family control and CEO member of the founding family; E (Entrepreneurial control; controlling owner appoints the CEO and is active in the board) and $\mathrm{M}$ (Management independent of owners).

Source: Glete (1994)

\begin{tabular}{|c|c|c|c|}
\hline Firm & \# Employees & Controlling owner & Type of control \\
\hline ASEA & 7000 & - & $\mathrm{M}$ \\
\hline Stora Kopparberg & 7000 & Wallenberg & $\mathrm{E}(\mathrm{M})$ \\
\hline Svenska Tändstricks AB & 5000 & Ivar Kreuger & $\mathrm{F}$ \\
\hline Grängesberg/LKAB & 5200 & - & M \\
\hline SKF & 5200 & $\begin{array}{c}\text { Mark/Carlander } \\
\text { Wallenberg } \\
\text { Skandinavbanken }\end{array}$ & M \\
\hline Uddeholm & 4100 & - & M \\
\hline Höganäs-Billesholm & 3900 & - & M \\
\hline L M Ericsson & 3500 & $\begin{array}{l}\text { K F Wincrantz } \\
\text { Ivar Kreuger }\end{array}$ & $\mathrm{FE}$ \\
\hline Husqvarna & 3300 & - & M \\
\hline Tobaksmonopolet & 3200 & Government & M \\
\hline Sockerbolaget & 3000 & - & M \\
\hline Ytterstforss-Munksund & 3000 & Svenska Handelsbanken & M \\
\hline Holmens Bruk & 3000 & Wahren & M \\
\hline Gimo-Österby & 3000 & Svenska Handelsbanken & M \\
\hline Sandviken & 3000 & Göransson/Magnusson & $\mathrm{F}$ \\
\hline Skånska Cement & 2600 & Wehtje & FM \\
\hline Götaverken & 2500 & Broström & $\mathrm{ME}$ \\
\hline Separator & 2300 & Cross-holdings & M \\
\hline NOHAB & 2300 & Göteborgs Handelsbank & M \\
\hline Billerud & 2200 & - & M \\
\hline Bergvik\&Ala & 2200 & Svenska Handelsbanken & $\mathrm{M}$ \\
\hline A K Fernsröm & 2100 & Fernström & $\mathrm{F}$ \\
\hline Iggesund & 2000 & Trygger/von Sydow & $\mathrm{ME}$ \\
\hline \multirow[t]{2}{*}{ Skönvik } & 2000 & Bunsow & M \\
\hline & & Svenska Handelsbanken & \\
\hline Malmö Yllefabrik & 1900 & $\begin{array}{c}\text { Schmitz } \\
\text { Skandinavbanken }\end{array}$ & $\mathrm{F}$ \\
\hline
\end{tabular}


Table 2: Ownership and controlling owners in the 25 largest industrial firms in Sweden in 1945. Type of controlling owners: F (Family control and CEO member of the founding family; E (Entrepreneurial control; controlling owner appoints the CEO and is active in the board) and $\mathrm{M}$ (Management independent of owners).

Source: Glete (1994)

\begin{tabular}{|c|c|c|c|}
\hline Firm & \# Employees & Controlling owner & Type of control \\
\hline ASEA & 23200 & Wallenberg & $\mathrm{ME}$ \\
\hline Uddeholm & 11000 & - & M \\
\hline Bofors & 9200 & Axel Wenner-Gren & M \\
\hline SKF & 8500 & Mark/Carlander & (E) \\
\hline & & Wallenberg & \\
\hline L M Ericsson & 7500 & ITT, SHB-Group & $\mathrm{E}$ \\
\hline & & Wallenberg & \\
\hline Stora Kopparberg & 7500 & Wallenberg & $\mathrm{E}$ \\
\hline SCA & 7000 & SHB-Gruppen & M \\
\hline Esselte & 6700 & - & M \\
\hline Fagersta & 6400 & SHB-Gruppen & M \\
\hline Svenska Tändstricks AB & 6200 & Wallenberg & $\mathrm{E}$ \\
\hline Grängesberg/LKAB & 6200 & - & M \\
\hline Götaverken & 6000 & $\begin{array}{c}\text { AB Gillius } \\
\text { (Management) }\end{array}$ & M \\
\hline Sandviken & 5900 & Göransson/Magnusson & $\mathrm{F}$ \\
\hline Husqvarna & 5800 & - & M \\
\hline Hellefors Bruk & 5300 & Custos & M \\
\hline Skånska Cementgjuteriet & 4500 & Wehtje & E \\
\hline Skånska Cement/IFÖ & 4500 & Wehtje & $\mathrm{F}$ \\
\hline Sockerbolaget & 4000 & - & M \\
\hline Volvo & 3700 & - & M \\
\hline Svenska Metallverken & 3500 & - & M \\
\hline Billerud & 3500 & - & M \\
\hline Boliden & 3500 & Skandinaviska Banken & M \\
\hline Separator & 3300 & Wallenberg & $\mathrm{ME}$ \\
\hline Höganäs-Billesholm & 3100 & - & M \\
\hline Kockums Mek & 3000 & Kockum & $\mathrm{E}$ \\
\hline Verkstad & & & \\
\hline
\end{tabular}


Table 3: Ownership and controlling owners in the 25 largest industrial firms in Sweden in 1967. Type of controlling owners: F (Family control and CEO member of the founding family; E (Entrepreneurial control; controlling owner appoints the CEO and is active in the board) and $\mathrm{M}$ (Management independent of owners).

Source: Glete (1994)

\begin{tabular}{|c|c|c|c|}
\hline Firm & \# of Employees & Controlling owner & Type of control \\
\hline SKF & 64759 & Wallenberg, Asken & $\mathrm{M}(\mathrm{E})$ \\
\hline \multirow[t]{2}{*}{ L M Ericsson } & 46400 & Wallenberg & $\mathrm{E}$ \\
\hline & & SHB-Gruppen & \\
\hline ASEA & 32401 & Wallenberg & $\mathrm{E}$ \\
\hline Svenska Tändsticks AB & 31800 & Wallenberg & $\mathrm{E}$ \\
\hline Volvo & 24268 & - & M \\
\hline Electrolux & 20964 & Wallenberg & $\mathrm{E}$ \\
\hline Alfa-Laval & 17837 & Wallenberg & $\mathrm{E}$ \\
\hline Skånska Cementgjuteriet & 17518 & Skånska Cement & M \\
\hline Grängesberg & 16010 & - & M \\
\hline Uddeholm & 15812 & Custos & M \\
\hline Sandviken & 14850 & Klingspor/Stenbeck & $\mathrm{E}$ \\
\hline SCA & 14121 & SHB-Gruppen & M \\
\hline SAAB & 13699 & Wallenberg & $\mathrm{E}$ \\
\hline BPA & 13000 & TUC & M \\
\hline Facit & 12832 & Ericsson & M \\
\hline Bofors & 12300 & - & M \\
\hline AGA & 12244 & SHB-Gruppen & M \\
\hline Stora Kopparberg & 11371 & Wallenberg & $\mathrm{E}$ \\
\hline Atlas Copco & 11196 & Wallenberg & $\mathrm{E}$ \\
\hline Skånska Cement & 9638 & - & M \\
\hline Scania Vabis & 9280 & Wallenberg & $\mathrm{E}$ \\
\hline Götaverken & 8274 & AB Gillius & M \\
\hline & & (Management) & \\
\hline Mo\&Domsjö & 8017 & Kempe/Carlgren & $\mathrm{F}$ \\
\hline Svenska Metallverken & 7775 & SHB-Gruppen & $\mathrm{F}$ \\
\hline Esselte & 7668 & - & $\mathrm{M}$ \\
\hline
\end{tabular}


Table 4: Frequency of ownership positions sorted both by size of ownership (capital) and by size of the 100 largest firms in terms of employment in 1950, 1963, 1978 and 1985. Source: SNS (1988).

1950

\begin{tabular}{|l|c|c|c|c|c|c|}
\hline & $<2.0 \%$ & $2.0-5.0 \%$ & $5.0-10.0 \%$ & $10.0-25.0 \%$ & $25-50.0 \%$ & $50.0-100 \%$ \\
\hline Firms 1-25 & 347 & 34 & 13 & 5 & 5 & 2 \\
\hline Firms 26-50 & 149 & 48 & 14 & 23 & 6 & 4 \\
\hline Firms 51-75 & 128 & 25 & 14 & 19 & 8 & 9 \\
\hline Firms 76-100 & 70 & 33 & 15 & 7 & 8 & 12 \\
\hline & & & & & & \\
\hline
\end{tabular}

1963

\begin{tabular}{|l|c|c|c|c|c|c|}
\hline & $<2.0 \%$ & $2.0-5.0 \%$ & $5.0-10.0 \%$ & $10.0-25.0 \%$ & $25-50.0 \%$ & $50.0-100 \%$ \\
\hline Firms 1-25 & 388 & 63 & 21 & 5 & 7 & 3 \\
\hline Firms 26-50 & 336 & 67 & 19 & 9 & 6 & 1 \\
\hline Firms 51-75 & 169 & 77 & 24 & 16 & 6 & 7 \\
\hline Firms 76-100 & 140 & 66 & 23 & 18 & 4 & 11 \\
\hline & & & & & & \\
\hline
\end{tabular}

1978

\begin{tabular}{|l|c|c|c|c|c|c|}
\hline & $<2.0 \%$ & $2.0-5.0 \%$ & $5.0-10.0 \%$ & $10.0-25.0 \%$ & $25-50.0 \%$ & $50.0-100 \%$ \\
\hline Firms 1-25 & 10 & 89 & 18 & 16 & 5 & 2 \\
\hline Firms 26-50 & 14 & 81 & 35 & 17 & 4 & 3 \\
\hline Firms 51-75 & 1 & 43 & 31 & 15 & 10 & 7 \\
\hline Firms 76-100 & 2 & 53 & 11 & 9 & 12 & 11 \\
\hline & & & & & & \\
\hline
\end{tabular}

1985

\begin{tabular}{|l|c|c|c|c|c|c|}
\hline & $<2.0 \%$ & $2.0-5.0 \%$ & $5.0-10.0 \%$ & $10.0-25.0 \%$ & $25-50.0 \%$ & $50.0-100 \%$ \\
\hline Firms 1-25 & 28 & 89 & 39 & 21 & 9 & 3 \\
\hline Firms 26-50 & 14 & 81 & 44 & 17 & 10 & 4 \\
\hline Firms 51-75 & 14 & 51 & 32 & 21 & 14 & 9 \\
\hline Firms 76-100 & 4 & 57 & 17 & 17 & 17 & 8 \\
\hline & & & & & & \\
\hline
\end{tabular}


Table 5: Ownership and controlling owners in the 25 largest industrial firms in Sweden in 1990. Type of controlling owners: F (Family control and CEO member of the founding family; E (Entrepreneurial control; controlling owner appoints the CEO and is active in the board) and $\mathrm{M}$ (Management independent of owners).

Source: Glete (1994)

\begin{tabular}{|c|c|c|c|}
\hline Firm & \# of Employees & Controlling owner & Type of control \\
\hline \multirow[t]{2}{*}{ ASEA Brown Boveri } & 215154 & Wallenberg & $\mathrm{E}(\mathrm{M})$ \\
\hline & & Brown Boveri & \\
\hline Electrolux & 150892 & Wallenberg & $\mathrm{E}$ \\
\hline \multirow{2}{*}{ Volvo } & 72213 & Volvo-Skanska & M \\
\hline & & Cross-Shareholding & \\
\hline Stora & 69700 & Wallenberg & $\mathrm{E}$ \\
\hline \multirow[t]{2}{*}{ Ericsson } & 66138 & Wallenberg & $\mathrm{ME}$ \\
\hline & & SHB-Gruppen & \\
\hline \multirow[t]{2}{*}{ SKF } & 49305 & Wallenberg & $\mathrm{ME}$ \\
\hline & & Skanska & \\
\hline Procordia & 45193 & Government/Volvo & $\mathrm{ME}$ \\
\hline \multirow[t]{2}{*}{ Skanska } & 31746 & Volvo-Skanska & M \\
\hline & & Cross Shareholding & \\
\hline SCA & 30139 & SHB-Gruppen & M \\
\hline Saab Scania & 29388 & Wallenberg & $\mathrm{E}$ \\
\hline Nobel Industrier & 26654 & Penser & $\mathrm{E}$ \\
\hline Sandvik & 26373 & Skanska & M \\
\hline $\mathrm{NCC}$ & 23178 & Johnsson's Foundations & E \\
\hline Trelleborg & 21939 & Dunker's Foundation & M \\
\hline Atlas Copco & 21507 & Wallenberg & $\mathrm{E}$ \\
\hline Alfa-Laval & 20809 & Wallenberg & $\mathrm{E}$ \\
\hline Esselte & 19545 & Lindholm & $\mathrm{E}$ \\
\hline ASEA & 18066 & Wallenberg & $\mathrm{E}$ \\
\hline BPA & 17948 & TUC & M \\
\hline AGA & 14559 & SHB-Gruppen & M \\
\hline Cardo & 14080 & Volvo & M \\
\hline MoDo & 12961 & Kempe/Carlgren (SCA) & $\mathrm{E}$ \\
\hline Svenskt Stål AB & 12014 & Government & ME \\
\hline SIAB & 9814 & Lundberg & $\mathrm{E}$ \\
\hline FFV & 9709 & Government & $\mathrm{ME}$ \\
\hline
\end{tabular}




\section{Table 6}

\section{Closed End Investment Funds' control of the Stockholm Stock Exchange (SSE) 1986-2000}

The total market value of equity controlled by closed-end investment funds (CEIFs) and as percentage of the SSE market capitalization (market value of CEIFs excluded), the personal investments (investments by foundations controlled by the family/ organization included) by the controlling owners of the CEIFs (i.e the capital amount the owners themselves have invested), the percentage of total market capitalization invested by the controlling owners of the CEIFs, and the ratio between value under control and the net capital investment by the controlling owners of the CEIF.

Panel A: Value under CEIF control (sum of firm values in which a CEIF is part of the controlling block, i.e. the largest voting block) in million SEK, value of SSE in million SEK with CEIFs excluded, the market value of the personal investments by the controlling owners of the CEIFs (controlled foundations included).

\begin{tabular}{|c|c|c|c|c|c|c|}
\hline Year & $\begin{array}{l}\text { Value under CEIF } \\
\text { control }\end{array}$ & $\begin{array}{c}\text { Value of } \\
\text { SSE (CEIFs } \\
\text { excluded) }\end{array}$ & $\begin{array}{c}\% \text { of SSE Value (CEIFs } \\
\text { excluded) under CEIF } \\
\text { Control }\end{array}$ & $\begin{array}{l}\text { Personal Investments on } \\
\text { SSE by the controlling } \\
\text { owners of the CEIFs }\end{array}$ & $\begin{array}{c}\text { Personal } \\
\text { Investments as } \\
\% \text { of SSE value }\end{array}$ & $\begin{array}{l}\text { Control/ } \\
\text { Capital }\end{array}$ \\
\hline 1986 & 284328 & 405505 & 70.1 & 25008 & 6.2 & 11.4 \\
\hline 1987 & 235598 & 402100 & 58.6 & 21063 & 5.2 & 11.2 \\
\hline 1988 & 342266 & 566403 & 60.4 & 31218 & 5.5 & 11.0 \\
\hline 1989 & 447512 & 701360 & 63.8 & 41022 & 5.8 & 10.9 \\
\hline 1990 & 296758 & 504560 & 58.8 & 31054 & 6.2 & 9.6 \\
\hline 1991 & 352133 & 516247 & 68.2 & 20444 & 4.0 & 17.2 \\
\hline 1992 & 368878 & 505439 & 73.0 & 20050 & 4.0 & 18.4 \\
\hline 1993 & 691817 & 831846 & 83.2 & 40135 & 4.8 & 17.2 \\
\hline 1994 & 587787 & 964558 & 60.9 & 33394 & 3.5 & 17.6 \\
\hline 1995 & 743420 & 1137772 & 65.3 & 41223 & 3.6 & 18.0 \\
\hline 1996 & 1067296 & 1743868 & 61.2 & 60963 & 3.5 & 17.5 \\
\hline 1997 & 1343580 & 1984227 & 67.7 & 75378 & 3.8 & 17.8 \\
\hline 1998 & 1373303 & 2249611 & 61.0 & 73156 & 3.3 & 18.8 \\
\hline 1999 & 2151551 & 3644555 & 59.0 & 106431 & 2.9 & 20.2 \\
\hline 2000 & 1786520 & 3134973 & 57.0 & 80259 & 2.6 & 22.3 \\
\hline
\end{tabular}

Panel B: Total market value controlled by Investor and Industrivärden (sum of firm equity values in which Investor or Industrivärden is part of the controlling block, i.e. the largest voting block) in million SEK, market capitalization of SSE (million SEK with CEIFs excluded), and personal equity investments on the SSE by the Wallenbergs and the SHB (foundations included), either through the CEIFs (Investor (Providentia, Export Invest) or via Industrivärden (Promotion/ Bahco)) or through direct investments.

\begin{tabular}{|c|c|c|c|c|c|c|}
\hline Year & $\begin{array}{l}\text { Value under } \\
\text { Wallenberg or } \\
\text { SHB control }\end{array}$ & $\begin{array}{l}\text { Market value of } \\
\text { SSE (CEIFs } \\
\text { excluded) }\end{array}$ & $\begin{array}{l}\% \text { of SSE Value } \\
\text { under Wallenberg } \\
\text { or SHB Control }\end{array}$ & $\begin{array}{c}\text { Personal Investments on } \\
\text { SSE by the Wallenbergs } \\
\text { and SHB }\end{array}$ & $\begin{array}{c}\text { Personal } \\
\text { Investments as } \\
\% \text { of SSE value }\end{array}$ & $\begin{array}{l}\text { Control/ } \\
\text { Capital }\end{array}$ \\
\hline 1986 & 214167 & 405505 & 47.6 & 14467 & 3.2 & 14.8 \\
\hline 1987 & 188426 & 402100 & 42.9 & 12659 & 2.9 & 14.9 \\
\hline 1988 & 284120 & 566403 & 46.0 & 20589 & 3.3 & 13.8 \\
\hline 1989 & 378846 & 701360 & 48.9 & 27034 & 3.5 & 14.0 \\
\hline 1990 & 275475 & 504560 & 50.3 & 21935 & 4.0 & 12.6 \\
\hline 1991 & 294597 & 516247 & 53.4 & 14691 & 2.7 & 20.1 \\
\hline 1992 & 310584 & 505439 & 56.8 & 15459 & 2.8 & 20.1 \\
\hline 1993 & 561866 & 831846 & 62.9 & 32699 & 3.7 & 17.2 \\
\hline 1994 & 560923 & 964558 & 54.6 & 28911 & 2.8 & 19.4 \\
\hline 1995 & 702468 & 1137772 & 58.1 & 36073 & 3.0 & 19.5 \\
\hline 1996 & 1004736 & 1743868 & 54.4 & 52806 & 2.9 & 19.0 \\
\hline 1997 & 1340257 & 1984227 & 63.4 & 66426 & 3.1 & 20.2 \\
\hline 1998 & 1341042 & 2249611 & 56.6 & 63944 & 2.7 & 21.0 \\
\hline 1999 & 2088542 & 3644555 & 55.0 & 96148 & 2.5 & 21.7 \\
\hline 2000 & 1632428 & 3134973 & 49.3 & 69707 & 2.2 & 23.4 \\
\hline
\end{tabular}

Source: Holmén and Högfeldt (2004b) 
Table 7 Effective marginal tax rates for different combinations of owners and sources of finance in 1960, 1970 and 1980 (real pre-tax rate of return 10\% at actual inflation rates) and in 1985, 1991 and 1999 at different inflations rates for listed firms.

\begin{tabular}{|c|c|c|c|}
\hline & Debt & New share issues & Retained earnings \\
\hline \multicolumn{4}{|l|}{1960} \\
\hline Households & 27.2 & 92.7 & 48.2 \\
\hline Tax exempt institutions & -32.2 & 31.4 & 31.2 \\
\hline Insurance companies & -21.7 & 41.6 & 34.0 \\
\hline \multicolumn{4}{|l|}{1970} \\
\hline Households & 51.3 & 122.1 & 57.1 \\
\hline Tax exempt institutions & -64.8 & 15.9 & 32.7 \\
\hline Insurance companies & -45.1 & 42.4 & 41.2 \\
\hline \multicolumn{4}{|l|}{1980} \\
\hline Households & 58.2 & 136.6 & 51.9 \\
\hline Tax exempt institutions & -83.4 & -11.6 & 11.2 \\
\hline Insurance companies & -54.9 & 38.4 & 28.7 \\
\hline \multicolumn{4}{|l|}{1985} \\
\hline $0 \%$ inflation rate & 50.4 & 43.7 & 46.0 \\
\hline $5 \%$ & 75.0 & 87.6 & 58.8 \\
\hline $10 \%$ & 102.1 & 129.2 & 68.8 \\
\hline \multicolumn{4}{|l|}{1991} \\
\hline $0 \%$ inflation rate & 29.0 & 17.6 & 40.3 \\
\hline $5 \%$ & 38.8 & 46.4 & 51.5 \\
\hline $10 \%$ & 47.7 & 76.6 & 60.4 \\
\hline \multicolumn{4}{|l|}{1999} \\
\hline $0 \%$ inflation rate & 36.2 & 56.2 & 47.3 \\
\hline $5 \%$ & 49.1 & 79.2 & 60.2 \\
\hline $10 \%$ & 61.9 & 103.1 & 70.5 \\
\hline
\end{tabular}

Note: All calculations are based on the actual asset composition in manufacturing and conform to the general framework developed by King and Fullerton (1984). The average holding period is assumed to be 10 years. A negative tax rate implies that the rate of return after tax is greater than before tax. For instance, a tax rate of 83 percent for a debt-financed investment owned by a tax-exempt institution in 1980 tells us that a real rate of return of 10 percent before tax becomes 18.3 percent taking the tax effects into account.

Source: Södersten (1984) and Öberg (2003). 
Figure 1

The Wallenberg Sphere in January 1996

Vote ownership is reported with equity ownership in parenthesis (reproduced from Sundin and Sundqvist, 1996).

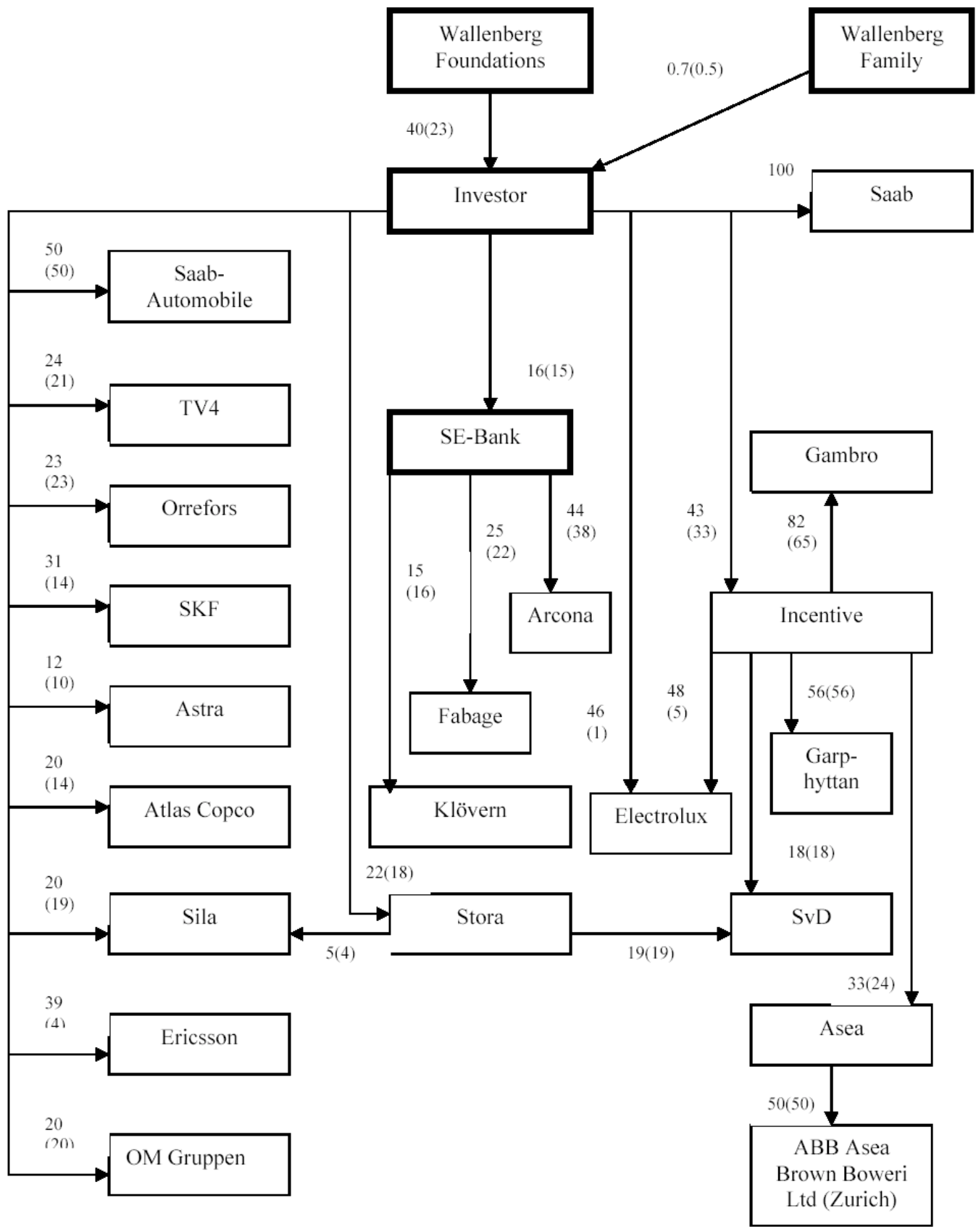




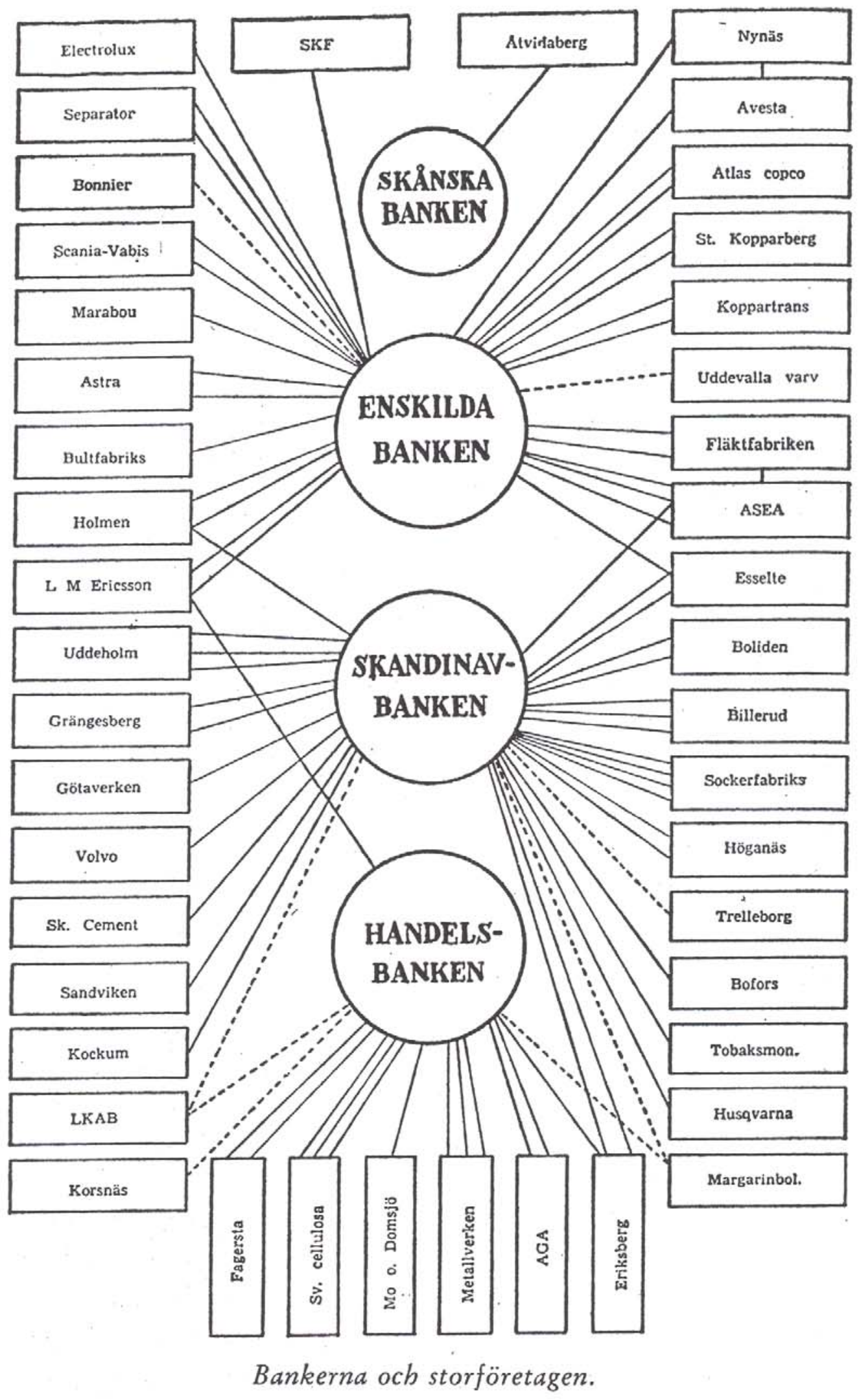

Fig. 1. The banks and the largest firms in 1960. The full line indicates that managing directors and/or board members of the bank are also board members of large firms that do their major borrowing and other financial activities with the bank. The dotted lines show that there is only an indirect relation as old managers or non-board members affiliated with the bank are also board members of client firms. 


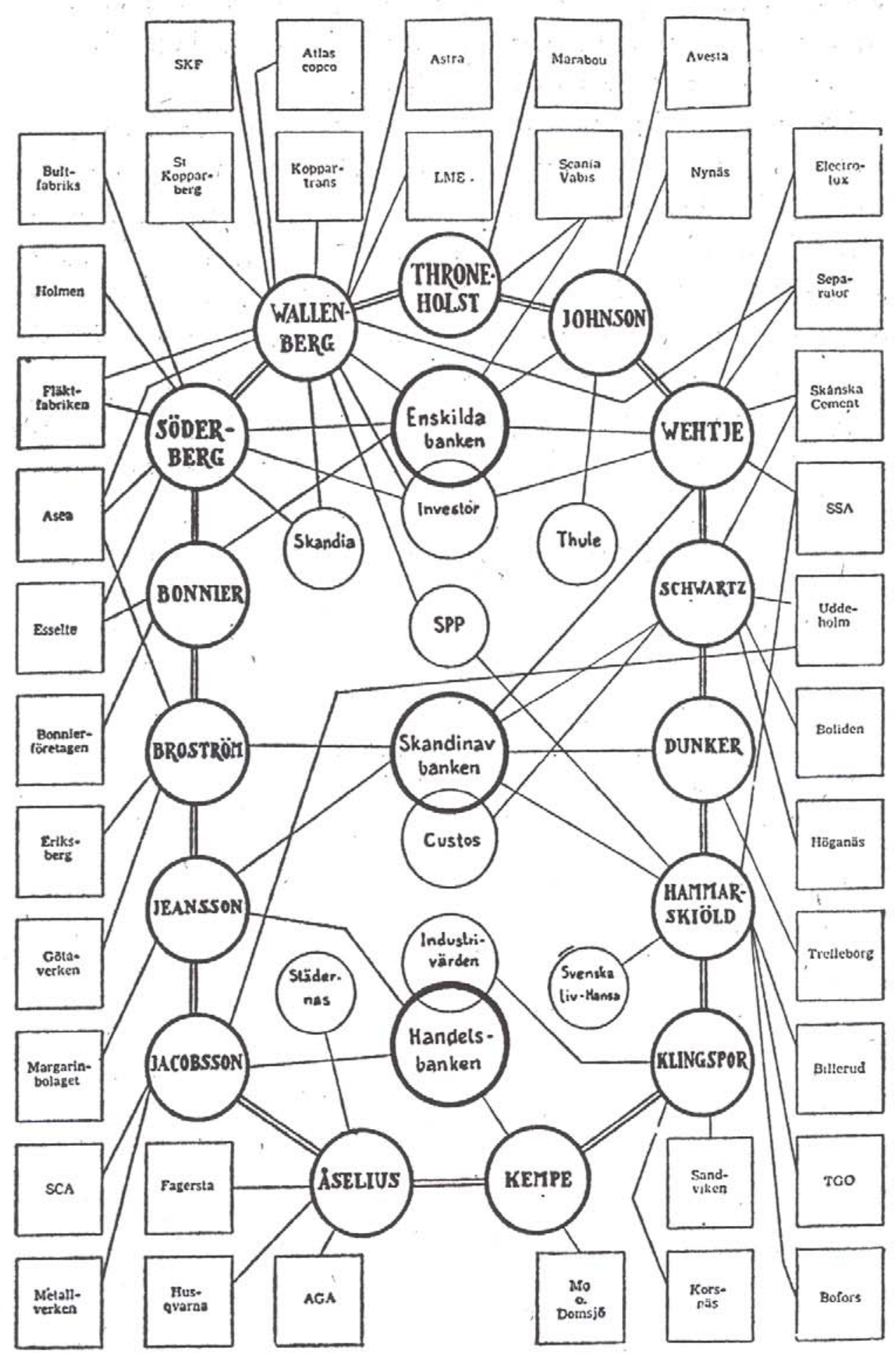

Femton finansfamiljer och deras intressen.

Fig 2. The 15 financial families and their controlling interests in the 1960s. The network between the financial families and the firms they control, their relations with the three major banks (Enskilda Banken, Skandinavbanken and Handelsbanken) and with holding companies (closed-end investment funds like Investor, Custos and Industrivärden) associated with the banks and with insurance companies (e.g. Skandia, Thule and SPP). 


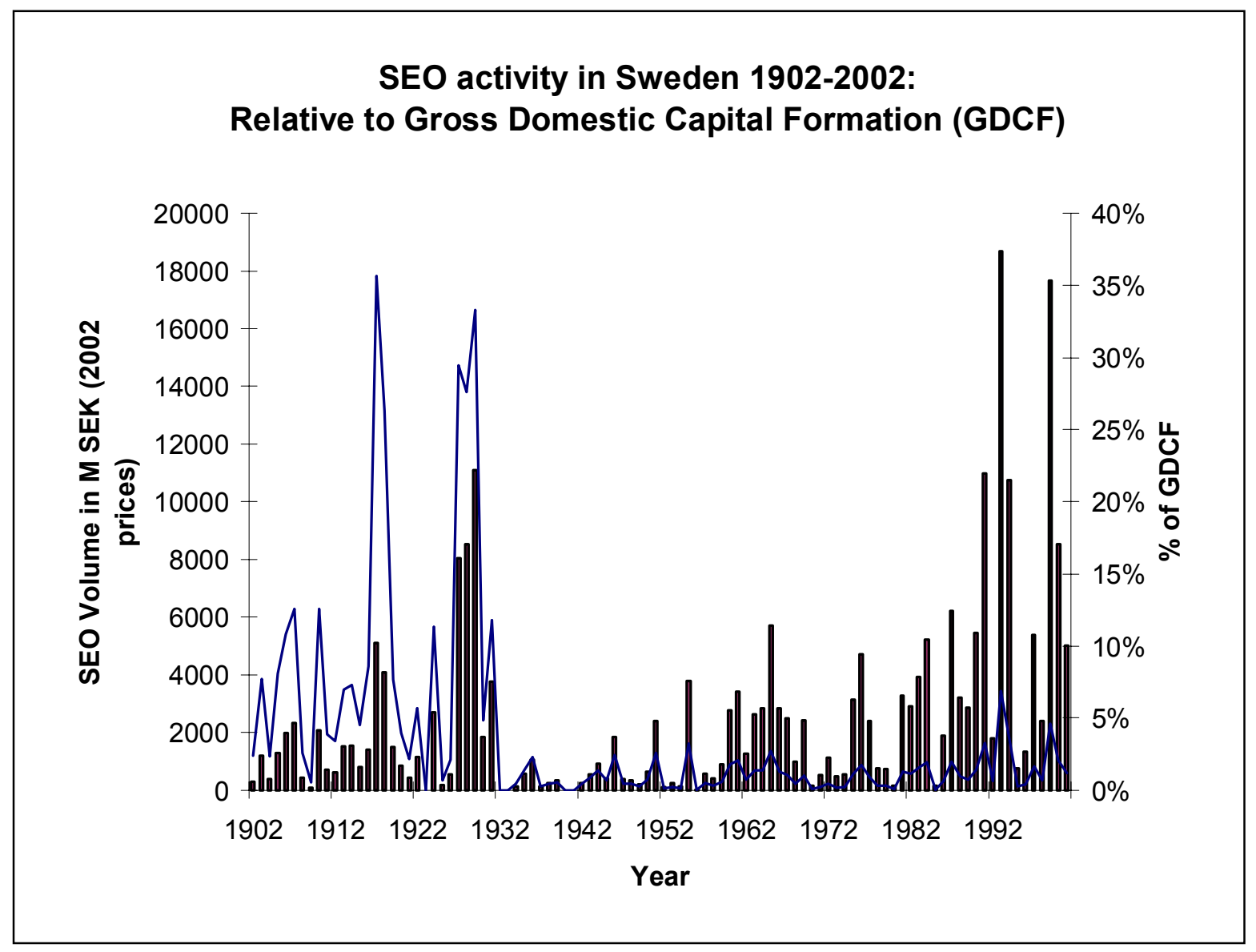

Sources: For 1902-87 Althaimer (1988), and for 1988-2002 Holmén and Högfeldt (2004b) 
50 largest firms in 2000 sorted by the period when they were founded

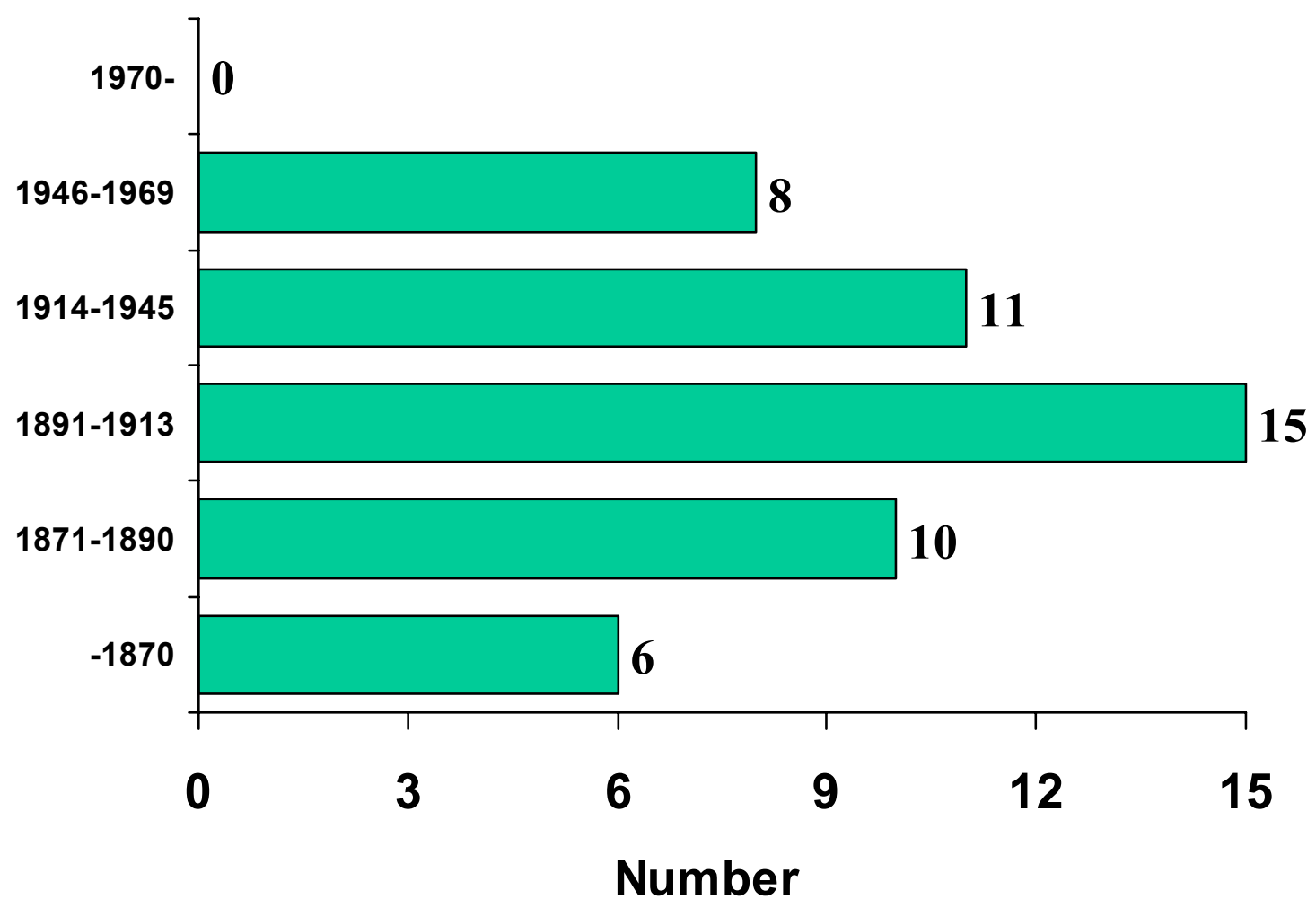

Source: NUTEK and ALMI (2001). 
Fig 1

Discount on Investor 1930-2002:

Share Price Relative to NAV (Net Asset Value)

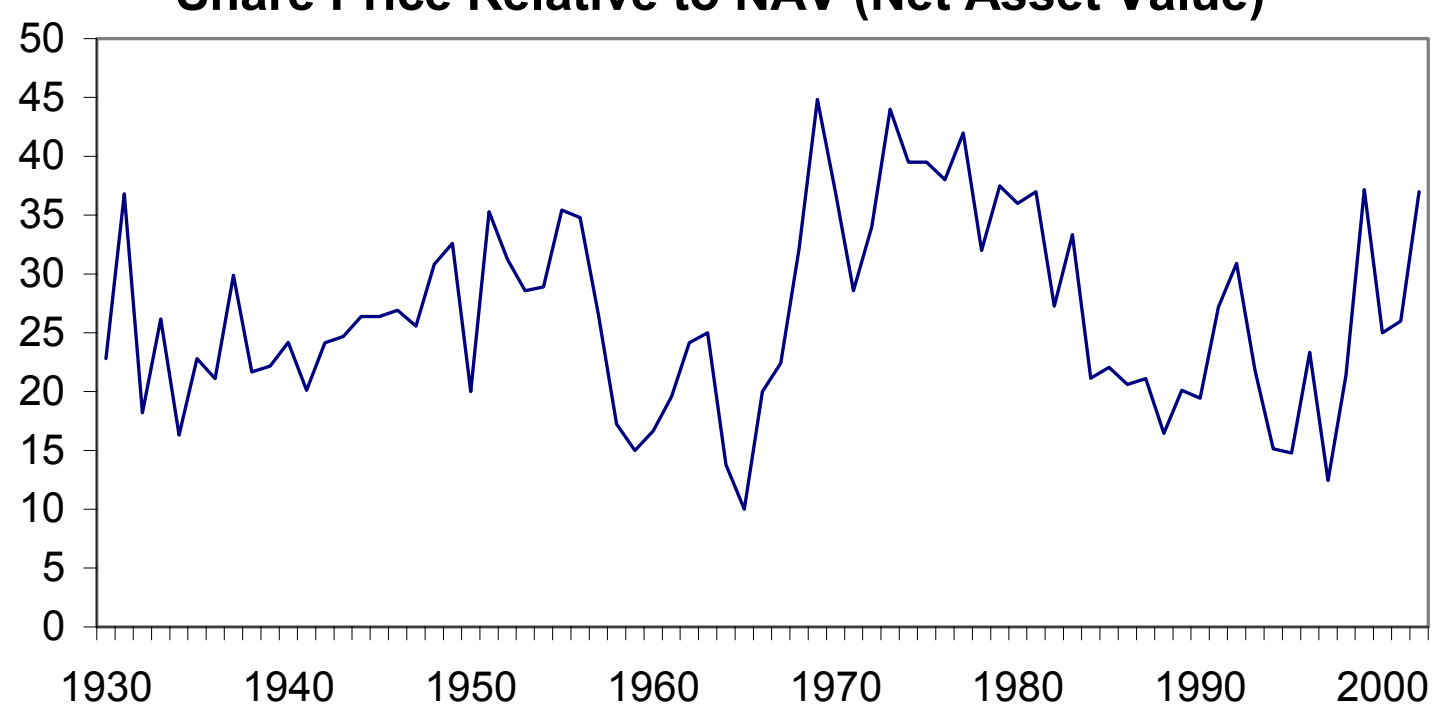

Sources: For 1930-1991, Lindgren (1994) (p 93, 149, 177 and 255) and for 1992-2002 Holmén and Högfeldt (2004b). 